\title{
FENOMENOLOGIA LITERÁRIA E LITERATURA FENOMENOLÓGICA SARTRIANAS
}

\author{
Sartre's literary phenomenology and phenomenological literature
}

\author{
Francisco Amsterdan Duarte da Silva \\ UFC \\ Emanuel Ricardo Germano Nunes \\ UFC
}

\begin{abstract}
Resumo: A predominância dos temas literários e fenomenológicos nos textos sartrianos dos anos 1930 já chamou atenção de vários especialistas e comentadores da obra do autor. É notável, entretanto, como os exames dos textos dessa época contentam-se, no mais das vezes, em apontar o paralelismo ou a contemporaneidade entre fenomenologia e literatura ali presente, sem realçar a fundamentação que uma parece conferir à outra e que constitui uma das questões mais interessantes que a filosofia sartriana levanta. Há que se incluir, na verdade, a estética literária de Sartre na compreensão de suas teses fenomenológicas; teses estas que, por outro lado, fornecem o solo filosófico da literatura sartriana, em termos tanto de autoria quanto de crítica. O propósito deste artigo é demonstrar, assim, uma dependência ou, se quisermos, implicação mútua entre literatura e fenomenologia não apenas central em relação àquele período da produção de Sartre como, também, determinante para seus projetos teóricos e ficcionais ulteriores.
\end{abstract}

Palavras-chave: fenomenologia; literatura; estética; ficção; filosofia sartriana.

\begin{abstract}
The predominance of literary and phenomenological themes in the Sartrean texts of the 1930s has already attracted the attention of various experts and commentators of the author's work. However, it is noteworthy how often the examinations of such texts merely point out the parallelism or the contemporaneity therein present between phenomenology and literature, without highlighting the groundwork these seem to bestow one another - one of the more interesting questions raised by Sartrean philosophy. In fact, one must include Sartre's literary aesthetics in the understanding of his phenomenological theses, which, on the other hand, provide the philosophical ground for Sartre's literature in terms of both authorship and criticism. The purpose of this article is therefore to demonstrate a dependence or, in other words, a mutual implication between literature and phenomenology not only central to that period of Sartre's production, but also determinant for his later theoretical and fictional projects.
\end{abstract}

Keywords: phenomenology; literature; aesthetics; fiction; Sartrean philosophy.

\section{§1 Gênese da imbricação fenomenologia-literatura}

1.1 O rapport da filosofia à literatura é objeto de teorização constante nos escritos de Sartre, conta com mais de uma abordagem conceitual ${ }^{1}$ e define até hoje seu legado como pensador. O fato de não ser claro se são os textos de (ou sobre) literatura que sempre acompanham, cronológica e tematicamente, os textos filosóficos de Sartre ou se é o inverso que ocorre evidencia, ao mesmo tempo, a centralidade dessa relação em

${ }^{1}$ Assim, o modo de pensar a literatura no recorte temporal e conceitual que privilegiamos aqui é um, o do engagement de O que é a literatura (1947) é outro, o da biografia existencial de Flaubert nos anos 1970 é outro... 
seu pensamento e o erro de se estabelecer uma hierarquia entre as duas formas de expressão. Na perspectiva sartriana, a obra literária não explica ou ilustra a tese filosófica, nem o texto filosófico leva a cabo uma apresentação conceitual da imagem literária. Mais do que uma usual relação de representação, Sartre parece - além de explicitar uma interseção - teorizar uma espécie de causação recíproca entre os dois registros ${ }^{2}$. Trata-se de um projeto de reinvenção do rótulo (aliás, demasiado simplista) de escritor-filósofo no interior do qual a coincidência dá lugar à exigência: ao invés de assumir o papel de filósofo que faz literatura ou literato afeito à teoria filosófica, Sartre se ocupa de uma filosofia que exige a expressividade da forma literária, bem como de uma literatura que exige a elaboração filosófica. Não é o caso comum do autor que narra e especula e transpõe em seus textos essa ambivalência. $\mathbb{E}$ antes a própria obra que demanda um escritor capaz de executar filosofia e literatura num só fôlego. Sartre reconhece a propósito que "o que eu conduzi desde minhas primeiras obras [...] é ao mesmo tempo filosofia e literatura; não justapostas, mas de forma que cada elemento dado é ao mesmo tempo literário e filosófico"3.

1.2 Qual é então o caráter dessa obra que não pode passar sem o duplo recurso da imagem e do conceito? O que há para ser dito que só pode ser dito por meio dessas duas estratégias de escrita - e que malograria na hipótese de se preferir uma sobre a outra? Bento Prado Jr., prefaciando a edição brasileira de Situações I, argumenta pela impossibilidade de se pensar em separado a filosofia e a literatura sartrianas como discursos que viriam adornar um ao outro, quando de fato é preciso saber ler a abertura de um ao outro, i.e., o modo pelo qual, em Sartre, a filosofia outorga o estatuto da literatura e vice versa:

Entre a filosofia e a literatura, trata-se de recuperar o poder de verdade da literatura (mesmo nas formas palas quais ela oculta a verdade de nossa experiência vivida) e de devolver à fillosofia uma linguagem viva que ela perdeu na sua produção/reprodução intramuiros nas instituições escolásticas .

Particularmente no texto sartriano, esse movimento de imbricação, causação ou exigência que conecta literatura e filosofia extravasa o nível formal. Como vimos o próprio Sartre afirmar, não se trata de uma justaposição gratuita. Há uma mensagem ou conteúdo que força o texto a operar simulltaneamente com imagens e conceitos, e que termina por nos forçar, enquanto leitores, a procurar os indícios do conceito na imagem e desta naquele. Já que a escrita sartriana exclui os lugares-comuns da literatura como via de acesso ao conceito e da filosofia como sofisticação da imagem, insistindo que o filosófico é o literário e que o literário é o filosófico, a tarefa passa a ser agarrar a ideia em plena, constante metamorfose entre uma forma e outra. Esta tarefa requer, no entanto, uma derradeira sutileza na medida em que literatura e filosofia convergem no quê mas não no como, isto é, dizem a mesma coisa e cooperam no mesmo universo, mas sem perder suas especificidades. Conforme alerta Bento Prado, "não se trata de

\footnotetext{
2 "A narração romanesca não ilustra a posteriori a concepção filosófica, ela a descobre e a torna concretamente sensível, compartilhável, ao inscrevêla nas dimensões do tempo e do espaço onde a liberdade é vivida e que a situam. Filosofia do vivido, filosofia subjetiva e concreta, fundada sobre a experiência singular do sujeito que a concebe, a filosofia de Sartre (seu materialismo histórico subjetivo, se quisermos) é em seu percurso mesmo uma filosofia narrativa: o romance e a autobiografia (o romance autobiográfico) são constitutivos de sua expressão. A teoria da liberdade exposta em o ser e o nada encontra n'Os caminhos da liberdade não sua encenação, mas sim sua prova, sua verificação concreta, assim como a teoria da práxis alienada exposta na Crítica da razão dialética encontra n'o idiota da famúlia, este 'romance verdadeiro' de Flaubert, sua passagem ao concreto, e o inacabamento do romance romanesco e do romance teórico evita nos dois casos que a teoria se feche sobre si mesma, lançando-a numa nova experiência: o inacabamento é a lei da prova da liberdade" (CONTAT, Michel; IDT, Geneviève. "Préface". In SARTRE, Jean-Paul. CEuvres romanesques. Paris: Gallimard, 2009, pp. xii-xiii). As traduçôes dos textos em língua estrangeira são nossas.

${ }^{3}$ SICARD, Michel. Essais sur Sartre. Entretiens avec Sartre (1975-1979). Paris: Ed. Galilée, 1989, p. 380; grifamos.

${ }^{4}$ PRADO JR., Bento. "Sartre e o destino histórico do ensaio". In: SARTRE, Jean-Paul. Situações I. São Paulo: Cosac Naify, 2005, p. 9.
} 
confundir filosofia e literatura, mas de abrir caminho para uma filosofia que seja capaz de exprimir a experiência mais concreta e de valorizar uma literatura que nos permita ver melhor a nós mesmos e o mundo presente ${ }^{\% 5}$. A escrita sartriana - em sua totalidade, sim, mas especialmente no recorte que ora privilegiamos - vai expressamente ao encontro dessa experiência mais concreta e dessa visualização apurada de nós mesmos e do mundo presente. Perscrutar o que significa para o autor o exercício da escrita filosófico-literária significa ter de dar conta dessa experiência e dessa visão.

1.3 Um aspecto decisivo no itinerário intelectual de Sartre, o qual moldará sua concepção de filosofia e literatura, deve nos servir de ponto de partida: a coincidência cronológica de suas descobertas da fenomenologia alemã e da literatura norteamericana. Os anos de 1933 e 1934 são o período no qual as teses centrais dos escritos sartrianos dessa década são gestadas. Sartre é então um jovem pesquisador que aproveita sua estadia num instituto de filosofia berlinense para estudar as obras seminais de Edmund Husser ${ }^{6}$. Mas ao mesmo tempo em que se aprofunda nas ideias fenomenológicas e redige seus primeiros artigos de forte repercussão Sartre se dedica à literatura ${ }^{7}$ : durante esses dois anos ele começa a trabalhar em seu primeiro e longamente planejado romance - A náusea. A preocupação romanesca, portanto, aliada à rotina de formação acadêmica, contextualiza a leitura, intensificada nos anos seguintes, que Sartre faz ainda de autores norte-americanos como John Dos Passos e William Faulkner. Ademais, à época dessa recepção da literatura norte-americana Sartre conduzia estudos sobre a evolução da técnica do monólogo interior ${ }^{8}$, sem que se saiba até que ponto tais estudos influenciaram ou foram influenciados por suas leituras. O duplo encontro, no entanto, nada tem de acidental, devendo ser antes lido como o resultado de uma busca pacientemente empreendida. É que as primeiras críticas sartrianas à predominância do intelectualismo ${ }^{9}$ na filosofia universitária e ao psicologismo excessivo da literatura francesas também coincidem. Nesse sentido, pode-se compreender a avidez com a qual Sartre buscará, na nova literatura norte-americana e no carismático movimento fenomenológico alemão, a indicação de ferramentas alternativas que lhe permitam desenvolver, no melhor estilo francês de narrativa e argumentação, os problemas que lhe interessam enquanto literato e filósofo. Buscaremos tematizar nas páginas a seguir a simultaneidade desses encontros, perfazendo um itinerário que vai do curto e enérgico artigo sobre o conceito husserliano de intencionalidade, introduzindo rapidamente a importante mediação da apologia cinematográfica, passando pelos ensaios sobre William Faulkner e indo até a presença da fenomenologia sartriana no escopo narrativo de seu primeiro romance ${ }^{10}$.

\section{§2 A preocupação imagética na fenomenologia sartriana}

2.1 "Você vê esta árvore, que seja. Mas você a vê no lugar mesmo onde ela está: à beira da estrada, no meio da poeira, só e torcida sob o calor, a vinte léguas da costa

\footnotetext{
${ }^{5}$ Ibidem, p. 9; grifos do autor.

${ }^{6}$ COHEN-SOLAL, Annie. Sartre. Trad. Milton Persson. São Paulo: L\&PM Editores, 1986 (p. 133) narra o episódio em que Sartre, no início de 1933, toma conhecimento pela primeira vez das pesquisas fenomenológicas por intermédio do então colega Raymond Aron.

${ }^{7}$ Cf. COOREBYTER, Vincent de. "Introduction". In: SARTRE, Jean-Paul. La Transcendence de l'Ego et autres textes phénoménologiques. Paris: Librarie Philosophique J. Vrin, 2003, p. 12.

${ }^{8}$ COHEN-SOLAL, Annie, op. cito, pp. 140-141.

${ }^{9}$ Definamos essa atmosfera acadêmica intelectualista como o estado de primazia da epistemologia e de um idealismo nos moldes kantianos, desfavorável às pesquisas de ontologia e aos métodos intuicionistas ou dialéticos (daí a recepção tardia de Hegel e, claro, de Marx; daí a lenta traduçăo dos textos de autores ligados à fenomenologia como Husserl e Heidegger).

${ }^{10}$ Para uma abordagem diversa, cf. CAMPOS, Carolina Mendes; ALT, Fernanda; EWALD, Ariane P. "A interrelação filosófico-literária do pensamento de Sartre: bases para uma psicologia fenomenológica do Eu". In: Revista de abordagem gestáltica, Goiânia, vol. 15, n. 9, 2009, pp. 126-132, onde a leitura do Sartre escritorfilósofo durante os anos 30 é ancorada num perfil conjunto do ensaio $A$ transcendência do ego e do conto $A$ infancia de um chefe, de O muro (1939).
} 
mediterrânea"11. Esta descrição bem poderia constituir a ambientação de uma cena narrativa, ou ainda um trecho de prosa poética, mas ela faz parte, de fato, de um artigo filosófico. Trata-se do pequeno texto Uma ideia fundamental da fenomenologia de Husserl: a intencionalidade, publicado por Sartre em 1939 e escrito na época de seus estudos berlinenses em 1933-34. Outras apresentações da novidade da fenomenologia husserliana já haviam sido feitas, por exemplo, em A imaginação (1936) e A transcendência do ego (1937). Mas esta sobressai por pelo menos três razões: primeiramente - o título o explicita - por se tratar de apresentar mais um conceito do que uum autor; em seguida pelo fato de o texto evidenciar a especial apropriação e mesmo ressignificação que Sartre opera em relação à fenomenologia de Husserl, em particular ao conceito de intencionalidade ${ }^{12}$. A terceira razão, a que mais nos interessa aqui, é que Uma ideia fundamental.. parece procurar estabelecer muito mais uma imagética da consciência do que uma teoria da consciência - por sua vez levada a cabo nos demais ensaios fenomenológicos que citamos acima. Isto porque, salvo por uma rápida explicação técnica do postulado husserliano "toda consciência é consciência de alguma coisa"13 , Sartre se ocupa ao longo do texto em descrever imageticamente a consciência a partir da intencionalidade, enquanto as consequências psicológicas e epistemológicas do conceito passam ao segundo plano.

2.2 A consciência que Sartre nos descreve situa-se a milhas de distância do modelo gnosiológico, intelectualista que alimentou a universidade francesa no século XIX cujos resíduos serviram de alicerce à "filosofia alimentar" cont4 contra a qual o autor polemiza. Esta metáfora digestiva vem denunciar "uma ilusão comum ao realismo e ao idealismo segundo a qual conhecer é comer" ${ }^{215}$. A consciência, pensada sob os paradigmas da representação e assimilação, teria como propriedade essencial a absorção dos conteúdos empíricos, seguida pela acomodação desses conteúdos no intelecto (ou mente, ou espírito) e pela redução de todo fenômeno a conteúdo mental, num processo onde a relação entre consciência e mundo é acima de tudo uma relação de possessão. A fenomenologia procede, ao contrário, por uma desubstancialização da consciência, pela crítica à imagem desta última como lugar ou recipiente onde nossas experiências viriam se alojar. Sartre anuncia o conceito de intencionalidade como a feliz alternativa ao desconforto de conceber a consciência segundo o estatuto da coisa; pois mesmo sob a insígnia da res cogitans insinua-se a concepção da consciência como coisa - coisa pensante, mas ainda assim coisa. Ao atrelar o pensar ao pensado, o perceber ao percebido, o desejar ao desejado e assim por diante, ao evidenciar a conexão de jure entre o ato de consciência e seu objeto, a fenomenologia, diz Sartre, situa ativamente a consciência no mundo, salvando-a da postura passiva a que fora condenada pelas primeiras epistemologias modernas. Pois se a consciência não subsiste sem seu correlato, se ela é sempre consciência de..., então ela não é um algo inerte em perpétua espera de um hóspede. Ela é precisamente essa exigência do fenômeno, esse deslocamento entre as coisas, entre os perfis dos objetos, de ente a ente, de experiência a experiência. "É que Husserl vê na consciência um fato irredutível do qual nenhuma imagem física poderia dar conta. Exceto, talvez, a imagem rápida e obscura da explosão"16。

${ }^{11}$ SARTRE, Jean-Paul. "Une idée fondamentale de la phénoménologie de Husserl: l'intentionnalité". In: SARTRE, Jean-Paul. La transcendence de l'Ego et autres textes phénoménologiques. Paris: Librarie Phillosophique J. Vrin, 2003, p. 87.

${ }^{12}$ Cf. COOREBYTER, op. cit.. p. 21: "Sartre não foi jamais um discípulo de Husserl, mas sim um fenomenólogo original - inclusive por suas deficiências -, que retém de Husserl somente aquilo que lhe convence e lhe convém. Importa dizer que as torções e distorções impostas por Sartre a Husserl ressaltam melhor ainda os motivos de sua adesão imediata à fenomenologia em 1933".

${ }^{13}$ SARTRE, Jean-Paul, op. cito, p. 88.

${ }^{14}$ Ibidem, p. 87.

${ }^{15}$ Ibidem, loc. cit

${ }^{16}$ Ibidem, p. 88. 
2.2a Explosão, arranque, fuga, deslizamento, turbilhão ${ }^{17}$ - são estas protoimagens que vêm substituir as metáforas visuais da folha ou da tábua com que os filósofos por muito tempo tentaram descrever a consciência, agora livre do estatuto de coisa; livre, ao mesmo tempo, do esquema dualista dentro-fora que equiparava o conhecer ao comer.

Se, por impossível que seja, você entrasse "dentro" de uma consciência, seria apanhado por um turbilhão e atirado para fora, rumo à árvore, em plena poeira, pois a consciência não tem "dentro"; ela não é senão o fora de sil mesma e é esta fuga absoluta, esta recusa de ser substância que a constituem como consciência ${ }^{18}$.

Pode-se, portanto, descrever a consciência, mas não entrar nela. Não é possível acessar a consciência a partir de dentro. Não por uma suposta inefabilidade do foro íntimo mas porque a consciência não tem dentro: tudo nela é fora, alhures, como um constante turbillhão que de pronto apanharia e expulsaria qualquer espectador. $\mathrm{O}$ ponto de vista do interior da consciência não existe, sequer para a própria consciência. Esta é uma ideia de fortes repercussões na técnica literária de Sartre. Ela repercutirá, como logo veremos melhor, a partir de um descentramento originário da consciência reflexionante, num descentramento narrativo da subjetividade no qual o discurso sobre a própria identidade é tão difícil e tênue quanto a descrição da identidade alheia. A exigência será então a produção de uma narratividade do fluxo de consciência que capte e estruture desde o fora os pensamentos, as percepções e os estados normalmente situados no interior do sujeito.

2.3 Além de uma imagética da consciência - inscrita, na verdade, numa releitura do problema da subjetividade -, a ideia de intencionalidade fornece também, para Sartre, uma imagem das coisas, um vislumbre fenomenológico de sula dimensão objetiva. Não se trata, é claro, de recair num empirismo dogmático no qual os objetos podem ser pensados independentemente da realidade humana, mas sim de perguntar pela autonomia do fenômeno tal qual ele se mostra a uma consciência que o experimenta originariamente sob a atitude da descrição, e não da representação. Em termos epistemológicos, portanto, a fenomenologia ressignifica, na acepção de Sartre, tanto o ato de conhecer quanto o papel do conhecedor e o sentido do conhecido. Em termos ontológicos, ela ensina que o conhecimento não é mais que uma forma entre outras de abordar o mundo e que, seja como for, sempre nos deparamos com as coisas em sua opaca irredutibilidade, e não como constructos de nossa própria substância espiritual nos quais deveríamos, no fim das contas, reconhecer apenas a nós mesmos: "Husserl devolveu às coisas seu horror e seu charme. Ele nos restituiu o mundo dos artistas e dos profetas: assustador, hostil, perigoso, com seus redutos de graça e de amor ${ }^{p 19}$.

2.4 Uma ideia fundamental... apresenta o legado teórico de Husserl de forma tão entusiasmada e com tal apelo visual ao ponto de podermos nos perguntar, com toda boa vontade, se a intencionalidade é aqui um conceito ou uma imagem. De fato o texto sartriano - e esta característica é típica da escrita de Sartre como um todo - demonstra uma avidez pela imagem que faz com que, às vezes, a metáfora esteja presente ali onde o argumento é chamado. Mas o uso sartriano da imagem em meio à escrita filosófica não denuncia nenhuma fraqueza, nenhuma falta de rigor em suas reflexões, como se isso fosse o último recurso, poderoso o suficiente para convencer o leitor. A imagem é empregada no momento em que o conceito já disse quase tudo e, no entanto, a lacuna da intuição permanece em branco, à espera de algo que a filosofia, por não ser uma disciplina experimental, em tese não poderia oferecer. $\mathbb{E}$ dessa lacuna tradicionalmente

\footnotetext{
${ }^{17}$ Ibidem, loc cit.

${ }^{18}$ Ibidem, loc. cit.

19 Ibidem, p. 89. Caberia expor noutro lugar em que medida essa interpretação sartriana da tarefa da fenomenologia distoa das diretrizes no fundo idealistas que Husserl lhe confere. Sobre isso, ver, p. ex., DESANTI, Jean-Toussait. "Sartre et Husserl ou les trois culs-de-sac de la phénoménologie transcendantale". Les temps modernes, Paris, n. 632-633-634, 2005, p. 571-584.
} 
ignorada que a imagem, no texto sartriano, vem se ocupar. É por aí que as árvores, as máscaras japonesas e os amigos Pierre ${ }^{20}$ recebem não apenas uma justificativa como também uma função filosófica bem específica perante o conceito.

$2.5 \mathrm{O}$ que insistimos em estabelecer é o papel fundacional da intencionalidade para a estética e as concepções literárias de Sartre: pois o reconhecimento da importância daquela ideia para a ontologia e mesmo as teorias psicológicas do autor é, pode-se dizer, comum entre os intérpretes de sua obra ${ }^{21}$. O lugar da intencionalidade na produção literária sartriana, no entanto, está ainda para ser devidamente sublinhado, embora não seja difícil apontar como uma ideia de literatura e um projeto literário já estavam em plena maturação à época da leitura de Husserl. Ressaltemos, nesse sentido, que, ainda em Uma ideia fundamental..., a crítica que denuncia primeiramente o caráter defasado do intelectualismo à la Brunschvicg pronuncia, no mesmo fôlego, apenas dois parágrafos depois: "eis-nos livres de Proust"22. Ou seja, é também todo um estilo literário - neste caso, toda uma literatura da interioridlade, da interiorização ou intelecção do mundo ancorada na teoria da representação - que a fenomenologia vem questionar. Trata-se para nós de elencar, a seguir, as consequências literárias da intencionalidade ou, noutras palavras, a maneira como a fenomenologia influi na teoria literária sartriana. Como uma imagética fenomenológica da consciência repercute, por exemplo, na narratividade romanesca; como, para Sartre, o registro de uma nova forma de pensar e fazer filosofia repercute numa nova forma de ler e escrever romances.

\section{$\S 3$ Parêntese: uma fenomenologia de inspiração cinematográfica}

3.1 "Havia um modo de expressão que Sartre privilegiava quase tanto quanto a literatura: o cinema"23. Aproveitamos o testemunho de Beauvoir para introduzir, en passant, um terceiro elemento neste estudo sobre a fenomenologia e a literatura sartrianas. Não fosse pela significativa produção cinematográfica de Sartre - tópico cujas abordagens, até hoje, são muito escassas ${ }^{24}$, não fosse ainda pela evidente centralidade do cinema, ao lado da literatura, nos seus escritos de juventude ${ }^{25}$, restaria, no fim das contas, uma razão forte o bastante para trazer o pensamento cinematográfico ao escopo deste texto: é que a reflexão de Sartre em torno do cinema influencia não apenas seu estilo literário como também a formulação de importantes conceitos de sua fenomenologia.

3.2 E preciso recuar um pouco, até meados dos anos 1920, para visualizar nas notas dicionarizadas do Carnet Midy e no ensaio Apologia do cinema (1924) a emergência da concepção sartriana de cinema cujos desdobramentos, nas décadas seguintes, serão roteiros como Resistência (não rodado, porém adaptado na peça $A s$ mãos sujas, de 1948) e A engrenagem (1946). É fácil notar que desde o início o cinema aparece para Sartre como tematização estética de uma preocupação que será sua até o fim da vida: a da relação indivíduo-mundo (ou -paisagem, ou -coletividade, ou -história). Sartre identifica de partida que um dos pressupostos essenciais da arte cinematográfica é a irrevogabilidade da correlação entre o sujeito e seu meio. O cinema, ao contrário de outras artes, digamos, cênicas, como o teatro, não pode abstrair da ambientação em

\footnotetext{
${ }^{20}$ A árvore do trecho de Uma ideia fundamental que citamos acima; a máscara japonesa que vem mencionada no mesmo texto; a raiz de castanheiro de $A$ náusea; as várias recorrências, nos argumentos de $A$ transcendência do ego, O imaginário e O ser e o nada, ao exemplo de Pierre como um sujeito hipotético.

${ }^{21}$ Cf. MOUTINHO, Luiz Damon Santos. Sartre: psicologia e fenomenologia. São Paulo: Brasilliense, 1995 e COOREBYTER, Vincent de, op. cit.

${ }^{22}$ SARTRE, Jean-Paul, op. cit., p. 89. Ver, a seguir, neste artigo, pp. 20-21.

${ }^{23}$ BEAUVOIR, Simone. La force de l'âge. Paris: Gallimard, 1960, p. 59.

${ }^{24}$ A literatura mais significativa nesse assunto inclui CONNOR, J. D. "Sartre and Cinema: The grammar of commitment". In: MLN. Baltimore, v. 116, n. 5, 2001, pp. 1045-1068; FAUTRIER, Pascale. Le cinéma de Sartre. http:/www.fabulla.org/lht/2/fautrier.html (último acesso em 11/03/19); e CHATEAU, Dominique. Sartre et le cinéma Paris: Séguier, 2005.

${ }^{25}$ O texto mais longo da edição dos Escritos de Juventude de Sartre (pela editora Gallimard) intitula-se Apologia do cinema.
} 
nome da figuração interior dos personagens. No cinema, o personagem deve encontrar, seja num objeto, numa paisagem, seja ainda no gesto de outro personagem, um correlato de motivo, de analogia, ou de consequência para seu movimento interior. No correr do filme, argumenta Sartre, o subjetivo e o objetivo estão mutuamente implicados, e essa implicação obriga o espectador a dispor de uma percepção de conjunto. "no cinema, o homem é recolocado em seu meio, o qual lhe é inseparável [...] O cinema dá a sensação do todo" 26

3.2a Sartre aproveita, aliás, a oportunidade da contraposição ao teatro para aproximar a estética do cinema de sua significação cultural. Numa conferência de 1931 intitulada $A$ arte cinematográfica Sartre aproveita algumas análises de Apologia do cinema para fundamentar sua tese de que o cinema ocupa na geração daquela época - a conferência é dirigida ao corpo estudantil do liceu do Havre, onde Sartre lecionava - o papel que o teatro ocupou para as gerações anteriores. No entanto, longe de consistir num aperfeiçoamento tecnológico do teatro, o cinema instaura, pela disposição plateiatela uma descontinuidade sinuosa em relação à experiência plateia-palco. Enquanto o teatro, por conta do formato mesmo da exibição, funciona com base na expectativa e no procedimento quase ritualístico desde o anúncio da peça até o momento dos aplausos, a experiência do cinema é marcada, sobretudo, pela espontaneidade ${ }^{27}$ e pelo caráter flexível do espetáculo, que pode ser visto várias vezes ao dia, por vários dias, com quaisquer vestimentas e até mesmo por fragmentos ("você assiste ao fim do filme e então, depois de uma espera de quinze minutos, ao início"28). O cinema é, portanto, "uma nova arte com suas próprias leis e seus próprios meios sociais, que não pode ser reduzida ao teatro" 29 , e que, Sartre exorta aos seus estudantes, "serve tanto para sua formação quanto o Grego ou a filosofia ${ }^{m 30}$.

3.3 É importante ter em mente que, pelo menos durante os anos 20-30, a concepção sartriana do cinema é fortemente marcada pela leitura que ele então fazia das obras de Henri Bergson. Mais do que isso, ao definir o cinema como arte da "mobilidade" e da "duração" no noções eminentemente centrais no pensamento de Bergson, Sartre parece tomar o filme como expressão estética do bergsonismo ${ }^{32}$. Da mesma forma que a obra de Bergson polemiza contra uma tradição metafísica mais ou menos homogênea no que cabe à concepção do tempo e da mudança, assim as técnicas cada vez mais sofisticadas do cinema vão de encontro a um emprego (material ou simbólico) precário desse tempo e dessa mudança ao qual as demais artes há muito se encontram conformadas. Dito de outra forma, é como se a filosofia de Bergson e a vanguarda cinematográfica (à época, para Sartre, representada pelos estúdios norte-americanos) concorressem para a mesma ressignificação, ali metafísica, aqui artística, da temporalidade e do movimento.

3.4 A maneira pela qual o cinema dá conta dessas duas ordens do real é o ritmo. Embora o recurso à ideia de ritmo seja obrigatório para se pensar também, por exemplo, a música e a dança, a especificidade do ritmo do cinema está em que se trata de uma regulação extremamente flexível da sucessão de imagens. No cinema o corte, o hiato, o intervalo entre as imagens integra a percepção do ritmo, e é na verdade a forma como cada imagem é disposta em relação às demais, a partir de fatores como duração da tomada, ângulo e mesmo iluminação, que definirá o ritmo próprio ao filme. Uma vez que

${ }^{26}$ SARTRE, Jean-Paul. "Carnet Midy". In: SARTRE, Jean-Paul. Écrits de jeunesse, Paris: Gallimard, 1990, pp. 445446.

${ }^{27}$ Cf. SARTRE, Jean-Paul. "Motion Picture art". In: SARTRE, Jean-Paul. The writings of Jean-Paul Sartre. Volume 2: Selected prose. Trad. Richard McCleary. Evanston: Northwestem University Press, 1974, pp. 53-54.

${ }^{28}$ Ibidem, p. 54 .

${ }^{29}$ Ibidem, 10. 55.

${ }^{30}$ Ibidem, loc. cit

${ }^{31}$ SARTRE, Jean-Paul. "Apologie pour le cinéma. Défense et illustration d'un Art intemational”. In: SARTRE, Jean-Paul. Ecrits de jeunesse, Paris: Gallimard, 1990, p. 390.

${ }^{32}$ Mesmo a despeito das posições de Bergson sobre essa relação, as quais, para dizer a verdade, não coincidem com a interpretaç̃̃o sartriana. Cf. o capítulo IV de BERGSON, Henri. "L'évolution créatrice". In: BERGSON, Henri. Osuvres. Paris: PUF, 2001, especialmente p. 753 et seq. 
ele é decidido e aplicado às imagens, o ritmo funciona, então, como uma lei no cinema (sua lei estética por excelência), conectando cada imagem, em sua particular autonomia, num só fluxo, numa unidade sintética indecomponível:

Longe de ser uma projeção espacializada da consciência, portanto fragmentária, reduzida a clichês, a fotogramas, há para Sartre uma unidade sintética do filme não decomponível, ainda que possamos detectar sob esse fluxo, análogo em aparência ao fluxo da consciência, uma lei secreta. É a organização rítmica subjacente das imagens que permite a transfiguração do real, a recriação imaginária do mundo operada pelo cinema e pela qual ele alcança o estatuto de uima $\operatorname{arte}^{33}$.

Eis a consequência derradeira (ou pelo menos a consequência que nos interessa aqui) da leitura bergsoniana que Sartre faz do cinema: na medida em que esta arte pressupõe uma nova lida com o tempo e o movimento, ela abre a perspectiva de uma nova concepção da realidade humana enquanto consciência. A analogia que, segundo Fautrier, Sartre estabelece entre o fluxo do filme e o fluxo da consciência, de alguma forma prepara o horizonte de sua compreensão da natureza da consciência a ser desenvolvida após seu contato com a fenomenologia de Husserl. Num olhar retrospectivo, poderíamos mesmo dizer que a teoria cinematográfica de Sartre antecipa sua fenomenologia, em termos de instrumental teórico como em termos de vocabulário. Se a hipótese procede, e se em Sartre as preocupações fenomenológicas e as literárias são interligadas, deverá ser possível então demonstrar como o seu pensamento em torno do cinema determina a ótica pela qual ele há de conceber (e fazer) a literatura.

3.4a De fato não é difícil notar, em diversas passagens dos textos de Sartre sobre o cinema, uma proximidade com suas teses fenomenológicas proporcional àquela entre estas mesmas teses e sua teoria da literatura. A orientação dessa proximidade, no entanto, não é a mesma num caso e noutro. Pois mesmo se, conforme já argumentamos, é possível vislumbrar uma preocupação imagética no cerne da fenomenologia sartriana, ainda assim há em Sartre, por assim dizer, um primado cronológico da fenomenologia sobre a literatura, no sentido de que tanto seus textos de crítica literária quanto seus romances sucedem seus estudos em torno do ser da consciência. Assim, ao passo que Sartre parece proceder da fenomenologia à literatura, sula concepção de cinema é anterior à sua interpretação, seus textos e mesmo seu conhecimento a respeito da fenomenologia. De sorte que é num estudo aprofundado de textos como Apologia do cinema que deveremos buscar a gênese primária da fenomenologia e, por consequência, da literatura sartrianas. É para essa linha interpretativa que nos encaminham as passagens como: "o fillme é uma organização de estados, uma fuga, um fluxo indivisível, elusivo como nosso $\mathbb{E} u^{\prime \prime 34}$. Não será digno de nota que ideias como organização de estados, fluxo indivisível e caráter elusivo do Eu sejam explicitadas e encadeadas num texto de 1924, portanto dez anos antes das teses levantadas em lugares como Uma ideia fundamental... A transcendência do Ego e $O$ imaginário? O fato de o filme ser considerado, ali, "uma consciência como a nossa"35 deve nos chamar atenção para que a fenomenologia sartriana é, antes de qualquer coisa, cinematográfica.

3.5 No cinema, argumenta Sartre,

A duração cotidiana, a duiração monótona de nossas vidas despiui-se de seu véu e se apresenta em sua inumana necessidade. Ao mesmo tempo, o cinema é de todas as artes a mais próxima ao muindo real: homens reais vivem em paisagens reais. A Montanha sagrada é uma montanha de verdade, e o mar em Finis Terrae é ưn mar de verdade ${ }^{36}$.

${ }^{33}$ FAUTRIER, Pascale. Le cinéma de Sartre, op. cit. $\mathrm{n} / \mathrm{p}$.

${ }^{34}$ SARTRE, Jean-Paul. "Apologie pour le cinéma. Défense et illustration d'un Art international", op. cit, p. 398.

${ }^{35}$ Ibidem, loc cit.

${ }^{36}$ SARTRE, Jean-Paul. "Motion Picture art", op. cit, p. 56 
Cada filme, portanto, não deixa de conter uma doutrina do tempo, mas também do espaço e dos objetos, que ultrapassa quaisquer noções de realismo artístico na mesma medida em que a filmagem ultrapassa a representação enquanto técnica ou categoria estética. O cinema traz à tona uma teoria realista onde cada filme equivale a um ensaio de ontologia, uma teoria que por meio dos mais diferentes pontos de vista nos procura demonstrar que os objetos tais como os percebemos, os fenômenos naturais e históricos tais como os experimentamos, os indivíduos tais como os vemos existem e atuam sobre nós, todos simultaneamente, e nós neles, de forma que o limite entre subjetividade e realidade objetiva é demasiado tênue e variável. Há uma "polifonia cinematográfica"37 que, ao conjugar palavra, som, imagem, cor, movimento etc. versa sobre o mundo real mais intensa e precisamente do que as artes clássicas ${ }^{38}$. Trata-se de um princípio ao qual Sartre dedicará uma atenção privilegiada, principalmente porque lhe interessará a possibilidade de adaptar em técnica narrativa a transição entre os elementos fílmicos, iniciativa levada a cabo, sobretudo, em Sursis (1947). Ainda veremos como e por que exemplos Sartre efetua essa transposição técnica do cinema à literatura ${ }^{39}$.

3.6 Uma última insistência a respeito do lugar privilegiado do cinema no desenvolvimento da filosofia e da literatura sartrianas: trata-se de um excerto de Sartre par Iui-même em que Sartre dá conta da origem, afinal, cinematográfica de uum de seus conceitos filosóficos mais fundamentais, o de contingência:

Sei que a ideia de contingência veio da comparação que me veio à tona espontaneamente entre a paisagem num filme a paisagem na realidade. A paisagem de um filme, o diretor providencia para que ela tenha certa unidade e uma relação precisa com os sentimentos do personagem. Enquanto que a paisagem da realidade não possui unidade. Ella possui uma unidade ocasional e isso me havia chocado bastante. $\mathbb{E}$ outra coisa que também me havia chocado muito era que num filme os objetos tinham um papel específico a desempenhar, um papel ligado ao personagem, ao passo que na realidade os objetos existem ao acaso $^{40}$.

A experiência cinematográfica aparece aqui como gênese (ou, na verdade, contra-gênese) da ideia de contingência. No fillme aquela inumana necessidade do tempo expande-se e domina o tecido do real, fazendo com que cada ente assuma um estatuto pensado, apriorístico, essencial em relação ao todo, estatuto de objeto calculável e imediatamente vinculável no plano do roteiro e da ordem simbólica. Obviamente esse processo se repete noutras artes. O cinema, porém, permite contrastá-lo da forma mais palpável à realidade cotidiana, à percepção natural do mundo, onde reinam a dissonância, a deformidade, o desencontro, o azar - a contingência. É interessante notar como esse contraste serve de base à compreensão sartriana do ser opaco e, no fundo, inominável das coisas, em oposição ao caráter essencialmente comunicável do ser humano. Ao mesmo tempo, tem-se na comparação paisagística entre o plano do cinema e a vida real a matéria-prima daquela intuição nauseante da contingência enunciada pelo protagonista Roquentin no romance de 1938.

\footnotetext{
${ }^{37}$ Ibidem, p. 58.

${ }^{38}$ Sartre assim descreve a polifonia cinematográfica: “às vezes, através daquilo cujo nome técnico é ‘dissolução', a transição de um motivo para outro é firme, lenta e imperceptível; outras vezes, quando se faz necessário, rápida e brutal. Também é possívell desenvolver vários temas simultaneamente por meio da "exposição múltipla" (Ibidem, p. 58). Ver, a seguir, neste artigo, pp. 31-32.

${ }^{39}$ Cf. os verbetes "Cinéma" e "Scénarios" em NOUDELMANN, François; PHILLIPE, Gilles. Dictionnaire Sartre. Paris: Honoré Champion, 2004, pp. 88-91 e pp. 452-453. Fréderic Jameson conduz uma interessante análise sobre - emprego de técnicas cinematográficas na trilogia romanesca sartriana Caminhos da Liberdade (Cf. JAMESON, Fredric. Sartre. The Origins of a Style New Haven: Yale University Press, 1961, p. 157 et seq.)

${ }_{40}$ SARTRE, Jean-Paul. "Extraits inédits du film "Sartre par lui-même". In: SARTRE, Jean-Paul. CEuvres romanesques. Paris: Gallimard, 2009, pp. 1698-1699.
} 


\section{§4 Fenomenologia e crítica literária: tempo e narratividade em Faulkner}

4.1 Se na obra sartriana as preocupações filosóficas - no caso, fenomenológicas e as literárias são levantadas e desenvolvidas, como queremos demonstrar, de forma simultânea, isso significa que seus textos de crítica literária, enquanto indicadores daquilo que Sartre busca na arte de sua época, funcionam como lentes de aumento das questões privilegiadas de suas próprias literatura e filosofia. Esse tipo de ocasião, portanto, nos permite reencontrar, dessa vez como critérios ou exigências estéticas, as ideias de temporalidade, intencionalidade e contingência que constituem, nos anos 1930, - arcabouço conceitual do jovem fenomenólogo. Abordaremos aqui uma das mais significativas dessas ocasiões: a crítica de Sartre a William Faulkner a partir de dois artigos escritos entre 1938 e 1939, textos que, cada um a seu modo, repercutiram nos debates literários da época, além de se tornarem decisivos quanto ao amadurecimento das técnicas narrativas sartrianas.

4.2 Talvez o princípio mais emblemático da crítica literária de Sartre seja aquele com o qual ele abre o texto Sobre O som e a fúria: a temporalidade em Faulkner. "uma técnica romanesca remete sempre à metafísica do romancista. A tarefa do crítico é destrinchar esta antes de apreciar aquela"4.1. Permanece impensada, no entanto, entre as inúmeras citações dessa passagem, a necessidade do recuo à metafísica tal como Sartre o propõe para uma apropriada elucidação ou apreciação da obra de arte. Por que a obra não compareceria suficientemente autônoma diante da análise crítica? Por que seria preciso considerar o romancista, se não como filósofo, pelo menos como adepto de um pressuposto filosófico que sua técnica viria enunciar? A resposta, porém, não precisa ser buscada alhures: Sartre percebe no exemplo de Faulkner a oportunidade perfeita de justificar a insuficiência das categorias estéticas em dar conta da técnica romanesca, de forma que a recepção do escritor norte-americano lhe serve não tanto para aplicar como para, na verdade, demonstrar sua tese; isso porque, ele explica logo a seguir, "a metafísica de Faulkner é uma metafísica do tempo"42. O tempo é um aspecto fundamental da narratividade. Não apenas porque a narrativa costuma exigir uma situação temporal na qual os acontecimentos vêm a se desenrolar ou porque a manipulação gramatical dos tempos verbais gira as engrenagens do texto narrativo. É porque essa atividade, seja à oral, seja à escrita, dá sempre mostras de uma relação com o tempo. Narrar as coisas que passaram, que se passam e que virão a se passar pressupõe a capacidade de compreender e representar pretérito, presente e futuro, além de uma maneira de se mover entre essas três dimensões cujo domínio é anterior ao aprendizado das palavras. O modo como contamos o tempo determina, portanto, o modo como contamos uma história. Daí que determinada forma de narrar diga de determinada forma de conceber e dispor o tempo.

4.3 Para Sartre, é a disposição do tempo no eixo da narratividade faulkneriana que repercute, em dimensão literária, naquilo que viria a ser a característica mais marcante dos romances de Faulkner, ensaiada em obras anteriores mas definitivamente consolidada apenas a partir de $O$ som e a fúria: a "técnica da desordem" como "inextrincáveis mesclas de passado e presente" " "passagens do presente ao passado, dos gestos às histórias ${ }^{\text {"4t5 }}$. Essas passagens e misturas acusam uma concepção e uma experiência do tempo não formatáveis no molde cronológico a partir do qual usualmente se pensa e se referencia o tempo, ou melhor, elas violam o ter-sido do passado, o ser do presente e o vir-a-ser do futuro em nome da construção de uma temporalidade integral e, supostamente, mais genuína do que aquela na qual estamos

\footnotetext{
${ }^{41}$ SARTRE, Jean-Paul. "À propos de Le Bruit et la Fureur. La temporalité chez Faulkner". In: SARTRE, JeanPaul. Situations, I Paris: Gallimard, 1973, p. 66.

42 Ibidem loc. cit.

${ }^{43}$ SARTRE, Jean-Paul. “Sartoris par W. Faulkner”. In: SARTRE, Jean-Paul. Situations, I. Paris: Gallimard, 1973, p. 11.

${ }^{44}$ Ibidem, loc. cit.

45 Ibidem, loc. cit
} 
acostumados a viver e a narrar. No registro da temporalidade faulkneriana, tal como Sartre a interpreta, a experiência não se dá mais no ou a partir do tempo. Ao invés, ela submete e distorce o tempo, ainda que sob o risco de torná-lo indiscernível, evanescente, a fim de fazer emergir do tecido da consciência a descrição plena e vigorosa do acontecimento. Dessa forma, se o regime do fluxo de consciência - forma narrativa privilegiada em Faulkner - pretende dar conta das coisas, dos fatos e de como eles são vividos, então é preciso que a memória, a atualidade e a expectativa do personagem coexistam de tal forma que os limites e as transições entre uma e outra não fiquem imediatamente claros, nem para quem lê, nem para quem conta. Estranho método para atingir a objetividade. No entanto, o rompimento com a ordem temporal - melhor, cronológica - é incontornável em se tratando de narrar o vivido pelas lentes de quem o vive. É como se para falar da decadência material e da fragmentação psicológica dessas famílias sulistas ex-aristocratas Faulkner sentisse a necessidade de recorrer a um tempo igualmente fragmentado, esparso, de arquitetura frágil. O acontecimento narrado, nesse esquema, é semelhante a um quebra-cabeças de cujas peças se pode dizer que algumas têm entallhes desgastados e quase irreconhecíveis, algumas são guardadas com zelo por seus atores ou espectadores, e outras foram perdidas para sempre, deixando espaços em branco os quais sequer o narrador pode completar.

4.3a Dentre todos esses quebra-cabeças que compõem o romance, os de Benjamin (ou Benjy), na primeira parte, são sem dúvida os mais difíceis ${ }^{46}$. Se ele é o idiota que narra as estórias da vida dos Compson, o som e a fúria são mais do que adereços à sula narrativa ${ }^{47}$, são seu próprio substrato. As perturbações e a inquietude incontrolável de sua mente elevam à segunda potência a desordem temporal do romance. É o seu transtorno mental que nos inicia, sem a menor coerência, à verdade da família. Faullkner chegou a debater diversas vezes com seu editor sobre a possibilidade de se utilizar tinta colorida na impressão desta seção do livro. A ideia era sinalizar com o contraste das cores as mudanças espaço-temporais da narrativa, cuja frequência, sob a perspectiva de Benjy, poderia vir, segundo o autor, a entravar ou cansar a leitura do romance. Convencido, no entanto, da incompatibilidade dessa ideia com os recursos de impressão disponíveis à época, Faullkner teve de se contentar com o uso, sempre que possível, do itálico para demarcar um deslocamento temporal no corpo da narrativa ${ }^{48}$.

4.4 Mas a hipótese de Sartre de uma correspondência entre temporalidade e narratividade rapidamente o obriga a limitar o mérito do romance de Faulkner à percepção e à aplicação literária dessa correspondência. Isto por detectar, primeiro, que a metafísica do tempo em questão é uma versão do instantaneísmo, da concepção do tempo como série dos instantes; segundo, que dentre os estratos dessa série Faulkner privilegia o passado como polo organizador da temporalidade. Uma coisa, na verdade, se confunde com a outra, já que isso só lhe é possível mediante a ideia do tempo como incessante passagem de um ponto ao outro onde o primeiro ponto, a origem, é a única referência fixa e capaz de determinar o sentido do fluxo. Nesse arranjo, só o apelo ao passado pode dar conta das experiências - não tanto vividas como na verdade acumuladas -, dado que o presente é incessantemente deposto, "uma soma perpetuamente recomeçada" ${ }^{\$ 49}$, e o futuro sequer é evocável, zona de indeterminação da qual nada pode ser dito porque não abriga propriamente nenhum acontecimento.

4.4a O instantaneísmo é uma concepção do tempo que, no fundo, traspõe à metafísica o primeiro postulado euclidiano sobre a constituição do segmento de reta a

\footnotetext{
${ }^{46}$ Para uma leitura meticulosa das perspectivas temporais presentes em cada uma das quatro seções de O som e a furia à luz da concepção sartriana de tempo e de sua teoria das emoç̃es, cf. SKIRRY, Justin. "Sartre on William Faulkner's metaphysics of time in "The sound and the fury". In: Sartre studies intemational, New York, vol. 7, n. 2, 2001, pp. 15-43.

47 "[...] Out, out, brief candle, / Life's but a walking shadow, a poor player / That struts and frets his hour upon the stage / And then is heard no more. It is a tale / Told by an idiot, full of sound and fury / Signifying nothing" (SHAKESPEARE, William. Macbeth. Cambridge: Cambridge University Press, 1999, p. 228 (ato V, cena V))

${ }^{48}$ Só em 2012 foi publicada uma edição colorida de O som e a fúria, pela editora inglesa Folio Society.

${ }^{49}$ SARTRE, Jean-Paul. "À propos de Le Bruit et la Fureur. La temporalité chez Faullkner", op. cit., p. 67. 
partir de dois pontos distintos: dados dois instantes, está dado também o tempo, o qual deve ser lido como o salto infinitesimal de um ao outro. Ou ainda: o fluxo temporal é a soma irreversível desses saltos. A analogia é útil na medida em que nos ajuda a compreender como a crítica de Sartre procura evidenciar a filiação do tempo (e por conseguinte - é preciso lembrar - da narratividade) de Faulkner à estratégia moderna de matematização da realidade encabeçada pela fillosofia de Descartes. Mais uma vez salta aos ollhos a inseparabilidade entre as críticas de uma posição filosófica e de uma forma de fazer literatura. A avaliação do desenvolvimento do tempo na ficção moderna pressupõe o diagnóstico dos impasses do instantaneísmo cartesiano.

Se para Descartes é a intuição de si (eu penso) que fornece a certeza do suijeito como substância (res cogitans), não há outra alternativa que entender o tempo como uma instância externa à consciência; dessa feita, o tempo deverá ser identificado ao objeto do mundo. Sendo assim, como falar em dimensões temporais? 苂 no instante que se dá a certeza de ser, ou melhor, a verdade penso, logo sou é indubitável quando enunciadla ${ }^{50}$.

O cogito cartesiano nos remete a um instante illhado, aparado de quaisquer prolongamentos para frente ou para trás ${ }^{51}$. 0 mesmo acontece, por outras vias, em Faulkner. Em Descartes, estando o humano condenado ao instante, apenas deus guarda o segredo do tempo; em Faullkner, a tarefa da constituição temporal deve ser cumprida pelo narrador - o que significa dizer que o tempo não é uma realidade e não passa de uma articulação ideal, uma montagem essencialmente literária. Mas se assim fosse, o que poderia ser narrado? Se o instantaneísmo faz sentido para a consciência que narra (pensa) a si mesma para si mesma - sobra para deus o trabalho de conciliar nosso tempo e sua eternidade -, ele se converte em nonsense tão logo se percebe que entre quem narra, quem é narrado (mesmo se for fictício) e quem recebe a narração é preciso haver um acordo comum a respeito do antes, do agora e do depois. O sistema do romance, ou de qualquer narrativa, supõe um tempo, não empírico, mas não menos real onde as diversas consciências possam se encontrar. Um aspecto deste raciocínio é que ele nos leva a pensar uma constituição intersubjetiva da temporalidade; outro, que nos interessa aqui, permite concluir que o estatuto do tempo, certamente, não é o da realidade positiva, do Em-si, mas ele não é por isso um irreal. O tempo adere ao ser da consciência (o Parasi). Da mesma forma que não são os dois pontos distintos que formam, a não ser virtualmente, a reta, mas sim o ato de conectá-los, o tempo não pode ser formado pela justaposição de instantes, a temporalidade consistindo não numa sequência ou série desses instantes, mas no ato da consciência de temporalizar tudo quanto se lhe apresenta, de se servir do esquema passado-presente-futuro para expressar a distância entre si e algo, essa distância que vimos Sartre caracterizar como intencionalidade.

4.4b O preço que Faulkner pagaria, então, por partir de uma concepção do tempo tributária do instantaneísmo, seria formatar sua narração numa enumeração de experiências vividas que se sobrepõem umas às outras, sem que o nexo ou o prolongamento dessas experiências possa ser pensado. Ler O som e a fúria é ouvir, portanto, não a voz, mas o eco de um narrador num presente fantasmático que "surge não se sabe de onde, repelindo um outro presente"52, numa atualidade ex nihilo. A inessencialidade do presente coincide, assim, com o império do passado e com a total ausência de medo, desejo, de tudo que pressuponha a intuição do porvir. O fluxo de consciência faulkneriano não é contínuo, mas é unidirecional: ele escoa até o aqui-agora e de súbito para, recomeçando segundo os ditames da memória: "parece que Faulkner

${ }^{50}$ SILVA, Luciano Donizetti da. "Tempo e temporalidade na filosofia de Sartre". In: Princípios, Natal, vol. 15, $\mathbf{n}$. 24,2008 , pp. 225-248, p. 235

${ }^{51}$ Ibidem, pp. 235-236.

${ }^{52}$ SARTRE, Jean-Paul. "À propos de Le Bruit et la Fureur. La temporalité chez Faullkner", op. cit., p. 66-67. 
capta, no próprio cerne das coisas, uma velocidade congelada"53 "No entanto", continua Sartre,

Essa imobilidade fugidia e impensável pode ser interrompida e pensada. Quentin pode dizer: quebrei meu relógio. Acontece que quando o disser seu gesto será passado. O passado é nomeável, narrável, ele se deixa - numa certa medida fixar pelos conceitos ou reconhecer pelo coração. Já havíamos notado, a propósito de Sartoris, que Faulkner sempre mostrava os acontecimentos quando estes já se tinham consumado. Em O som e a fúria tudo se passa nos bastidores: nada acontece, tudo aconteceu. E isso que permite compreender esta estranha formulaçao de um dos heróis: "Eu não sou. Eu era" 54 。

4.4c Curiosamente, a literatura de Faulkner permite pensar, na margem, o elo profundo entre metafísica e antropologia, já que um narrador cujos olhos estão voltados para o passado e só nos fala do presente à medida que ele passa só nos pode dar conta de um indivíduo cuja existência se encontra sempre consumada e que só pode ser definido como "um total sem porvir. 'soma de suas experiências climáticas', "soma de suas desgraças', 'soma do que se tem': passa-se um traço a cada instante, já que o presente não é nada mais que um ruído sem lei ou que um futuro passado" ${ }^{\prime \prime 5}$. A crítica da técnica romanesca, ao pressupor a crítica à metafísica do romancista, tangencia muito naturalmente uma concepção da realidade humana. No caso de Faulkner aprofundaremos este passo dentro em pouco - o que se tem é uma ideia do ser humano como uum circuito (ou soma) cujas partes já estão dadas, ưm todo ao qual não se acrescenta nada e que a narração vem apenas explicitar.

4.5 Seria então mais acertado dizer, pela ótica da leitura sartriana, que o que embasa a narratividade de Faulkner é uma metafísica, não do tempo, mas do passado. Pois não é outra coisa senão a intromissão constante do passado no presente intromissão que chega ao ponto de toldar o horizonte do futuro - que funda aí a possibilidade da narração, numa espécie de positivismo de retrospecto no qual a evidência da verdade é o ter-sido: a história pode ser contada porque, e somente porque, foi vivida. A temporalidade centrada no passado, contudo, não deixa de ser uma abordagem do tempo mais criteriosa do que a dos relógios, e a ficção, nesse sentido, é mais exata do que a física, já que nos permite vislumbrar não só a aparência como a proveniência e o sentido da ordem temporal:

Seu passado [o dos personagens de Faulkner], que está em ordem, não se ordena conforme a cronologia. Trata-se de fato de constelações afetivas [... ] a ordem do passado é a ordem do coração. Não se deve crer que o presente, quando passa, torna-se a mais próximo de nossas lembranças. Sua metamorfose pode tanto fazê-lo escoar ao fundo de nossa memória como também conduzi-lo à superfície dela; apenas sua densidade própria e a signifícação dramática de nossa vida decidem o seu nível ${ }^{56}$.

O tempo vivido não coincide sempre com o tempo numericamente contado. A experiência do tempo, como apontávamos há pouco, não se conforma à cronologia; pelo contrário, ela a desafia, funcionando a partir de uma constelação de fatores muito mais decisivos do que os relógios ${ }^{57}$ : os afetos, as emoções, a imaginação, enfim, os projetos

\footnotetext{
${ }^{53}$ Ibidem, p. 67. Sobre a "temporalidade paralisante de Faulkner", cf. BASTOS, Jackson Valentim. "Sartre, Faulkner e a técnica literária como expressão do humano". Mimesis, Bauru, vol. 32, n. 1, 2001, pp. 19-28, p. 23.

${ }^{54}$ SARTRE, Jean-Paul. "À propos de Le Bruit et la Fureur. La temporalité chez Faulkner", op. cit, pp. 67-68; os grifos são nossos.

${ }^{55}$ Ibidem, p. 68

${ }^{56}$ Ibidem, p. 69

57 "No universo faulkneriano, os relógios [...] simbolizam o tempo da sociedade" (OORE, Irène. "Sartre critique de Faulkner". In: Dalhousie French Studies, Halifax, vol. 52, 2000, pp. 127-138, p. 131).
} 
humanos ${ }^{58}$. No fim das contas, a elucidação, em termos metafísicos ou ontológicos, da temporalidade depende, para Sartre (ideia devida sem dúvida à leitura de Heidegger), de uma antropologia filosófica que saiba buscar na consciência do tempo a perspectiva humana (do Dasein ou do Para-si...) do Ser. Dito de outra forma, o mérito parcial de Faulkner, de acordo com Sartre, está em ter demonstrado que não se compreende o humano a partir do tempo objetivo (a consciência a partir da duração contínua e uniforme). O tempo é que precisa ser compreendido como temporalidade, como abertura do humano ao ser. A consciência não pode aderir à objetivação do tempo simplesmente porque ela não está no tempo, ela é temporal. O que soa contra-intuitivo para alguém habituado aos modelos descritivos da física moderna é que, na metafísica de Faulkner, na fenomenologia de Sartre, a compreensão do ser do tempo não passa sem a compreensão do ser humano como temporal.

4.6 A caracterização do privilégio do passado na literatura de Faullkner permite pensar uma esclarecedora afinidade artística deste autor com a obra de Proust. E não apenas artística, se quisermos reforçar a insistência sartriana na relação metafísicatécnica romanesca. De qualquer forma, trata-se de compreender que a literatura faulkneriana desenvolve e como que aperfeiçoa a ideia de tempo que orientara Proust. Isso significa que é possível observar um progresso de Em busca do tempo perdido até $O$ som e a fúria no que diz respeito à expressão do tempo na literatura romanesca. Sartre vai mais longe ainda ao afirmar que "para dizer a verdade, a técnica romanesca de Proust deveria ter sido a de Faulkner. era a consequência lógica de sua metafísica" ${ }^{" 59}$. E continua: "a eloquência, o gosto pelas ideias claras, o intelectualismo impuseram a Proust manter pelo menos as aparências da cronologia"60. Um constrangimento de estilo seria, então, o elemento que separa o escritor francês do norte-americano e impede que se estabeleça de imediato, por via da crítica, uma vizinhança de forma e conteúdo a qual o próprio texto de Proust permite reivindicar. Basta que se resgate, a propósito, uma interessante fala do personagem Bloch em No caminho de Swann, primeiro volume da Recherche:

Nunca me deixo influenciar pelas perturbações da atmosfera nem pelas divisões convencionais do tempo. Reabilitaria de boa vontade o uso do cachimbo de ópio e do cris malaio, mas ignoro o uso desses instrumentos infinitamente mais perniciosos e além disso estupidamente burgueses: o relógio e o guarda-chuva ${ }^{61}$.

Deparamo-nos, nesta passagem, com o mesmo desprezo pelo tempo cronológico que nos personagens de Faulkner aparece quase como um traço de caráter. Nos dois casos o não uso ou a destruição do relógio dão conta da dupla iniciativa de recusa da instrumentalização do tempo e de busca por um acesso mais originário e mais autêntico do passado. No entanto, a problematização literária do tempo não é uma peculiaridade partilhada exclusivamente pelos dois escritores. Sartre vê antes os casos de Faulkner e Proust como partícipes de um fenômeno de época, como matizes de uma estratégia de manipulação do tempo comum a toda uma geração de escritores:

É preciso procurar a razão profunda dessa aproximação num fenômeno literário bastante geral: a maioria dos grandes escritores contemporâneos - Proust, Joyce, Dos Passos, Faulkner, Gide, V. Woolf - tentou, cada qual à sua maneira, mutilar o tempo. Alguns o privaram do passado e do futuro para reduzi-lo à pura intuição do instante; outros, como Dos Passos, fizeram dele uma memória morta e

\footnotetext{
${ }^{58}$ Aliás, estes fatores são à época os temas das pesquisas fenomenológicas de Sartre: desde o Esboço para uma teoria das emoções, passando por A imaginação e O imaginário e indo até O ser e o nada.

${ }^{59}$ SARTRE, Jean-Paul. “À propos de Le Bruit et la Fureur. La temporalité chez Faulkner”, op. cit.. p. 71.

${ }^{60}$ Ibidem, loc cit.

${ }^{61}$ PROUST, Marcel. Du coté de chez Swann Paris: Gallimard, 1946, p. 129. 
encerrada. Proust e Faullkner simplesmente o decapitaram, suprimiram seu porvir, quer dizer, a dimensão dos atos e da liberdade ${ }^{62}$.

Na esteira dessa percepção, Sartre anuncia por volta de 1939 um estudo sobre a "dissolução do tempo na literatura contemporânea"63. Trabalho este que não chega a ser desenvolvido, mas que é, certamente, esboçado nos artigos de análise dos romances de Faulkner.

4.6a Mas se a crítica permite diagnosticar o mal-entendido filosófico na raiz daquela prática literária, identificar as razões pelas quais o erro é erigido em lógica ulltrapassa a discussão. Para Sartre o fator determinante dessa distorção escapa ao plano da literatura e mesmo à dimensão teórica. "Como explicar por que Faulkner e tantos outros autores escolheram essa absurdidade tão pouco romanesca e tão pouco verídica?" - ele se pergunta:

Creio que é preciso procurar a razão disso nas condições sociais de nossa vida presente. O desespero de Faulkner me parece anterior à sua metafísica: para ele, como para todos nós, o porvir está vedado. Tudo o que vemos, tudo o que vivemos, nos incita a dizer: "Isso não pode durar" - e no entanto a mudança não é sequer concebível, a não ser na forma de cataclismo ${ }^{64}$.

Temos aí as primeiras indicações do caminho a ser perseguido por Sartre no seu pensamento da literatura: a metafísica do escritor elucida sua obra, mas é a situação do escritor - a forma como ele vive suas circunstâncias históricas e sociais - que elucida sua metafísica (e por consequência sua obra). Se essa ideia é aqui, em poucas linhhas, aplicada a Faulkner, ao longo das próximas décadas ela haverá de orientar livros inteiros consagrados à compreensão literária e existencial de figuras como Baudelaire, Jean Genet, Flaubert e, claro, o próprio Sartre (em As palavras).

4.7 Sublinhamos em citação recente uma importante característica que Sartre atribui ao empreendimento literário do qual Faulkner faria parte: a supressão do porvir, da "dimensão dos atos e da liberdade" ${ }^{\text {"65. }}$. Essa indicação nos permite retomar a ideia da repercussão antropológica da tematização literária do tempo. A esta altura o encadeamento dessas questões deve poder ser visualizado com bastante clareza: se a literatura não representa o tempo no típico esquema cronológico, mas sim como função da experiência da consciência, isso significa que a ordem do tempo na narratividade é sempre índice para uma imagem da realidade humana. Ora, se de acordo com Sartre a realídade humana é passível de uma definição filosófica a partir de uma descrição do ser da consciência - a ontologia do Para-si como uma antropologia fenomenológica -, temos que a estrutura da temporalidade no romance e na consciência em geral implicam-se um ao outro. O tempo dos personagens está assim para a temporalidade de suas consciências como para a do ser humano em gera ${ }^{66}$. Por isso a crítica do privilégio do passado e de sua constante atualização narrativa no romance de Faulkner é inseparável, para Sartre, da crítica à concepção do humano como ser que se organiza a partir do (e cuja facticidade acaba por se reduzir ao) seu passado. E daí que a anulação do futuro na obra literária (a mutilação do tempo $0^{67}$ pela literatura contemporânea) equivallha à desvinculação da liberdade do horizonte das ações, ou seja, a uma mutilação do ser humano. Sartre explica, a esse respeito, que

${ }^{62}$ SARTRE, Jean-Paul. "À propos de Le Bruit et la Fureur. La temporalité chez Faulkner", op. cit., p. 71; destacamos.

${ }^{63}$ COHEN-SOLAL, Annie, op. cit., p. 178: em carta de 1939, citada sem informações de data ou destino.

${ }^{64}$ SARTRE, Jean-Paul. "À propos de Le Bruit et la Fureur. La temporalité chez Faulkner", op. cit.., p. 74.

${ }^{65}$ Ibidem, p. 71.

${ }^{66}$ Cf. DANELON, Márcio. "A temporalidade na constituição da consciência na antropologia sartriana". In: Reflexão, Campinas, vol. 30, n. 87, 2005, pp. 95-110.

${ }^{67}$ SARTRE, Jean-Paul. “À propos de Le Bruit et la Fureur. La temporalité chez Faulkner”, op. cito, p. 71. 
A consciência só pode "ser no tempo" sob a condição de se tornar tempo mediante o próprio movimento que a torna consciência; é preciso, como diz Heidegger, que ela se "temporalize" [... ], que ela se lance à frente de si mesma futuro adentro; só se pode compreender o que ela é por aquilo que ela será; ela se determina em seu ser atual por suas próprias possibilidades ${ }^{68}$.

Essa reflexão aponta, como não se pode deixar de notar, para o locus central da filosofia de Sartre. Por um lado, ela nos inteira do projeto paralelo a todo estudo sartriano da consciência e que orienta, no fundo, todos os seus trabalhos teóricos iniciais: a fundamentação fenomenológica da liberdade. Por outro, indica com alguma antecipação a análise do comprometimento ontológico (além de político) da arte e do escritor com a liberdade. Se a crítica de Faulkner é tão importante, conforme argumentamos, para a devida apreensão do significado do colóquio com a literatura entretido pela fenomenologia de Sartre, é porque ela procura dar conta do estágio mais aperfeiçoado de todo um estilo de pensar e fazer literatura ${ }^{69}$. Ao mesmo tempo, ela contribui para a elaboração de uma arte capaz de demonstrar que "o homem definitivamente não é a soma do que tem, mas a totalidade do que ainda não tem, do que poderia ter ${ }^{977}$. Trata-se, portanto, de romper com uma representação estética do passado como destino e do determinismo antropológico em nome de vuma literatura centrada na ideia de liberdade.

\section{$\S 5$ A náusea: romance fenomenológico}

5.1 A náusea é, antes de tudo, uma espécie de projeção autobiográfica do jovem Sartre. A experiência solitária de Roquentin em Bouville, imerso numa pesquisa acadêmica inconclusa e tomado por descobertas que desatinam completamente o roteiro de sua vida, é uma réplica romanesca dos anos 1933-34 do autor ${ }^{71}$. Conforme apontamos, Sartre passou esse período em Berlin, lendo e escrevendo sobre fenomenologia e literatura. Além disso, Antoine Roquentin está para o Sartre acadêmico e professor como Mathieu Delarue está para o Sartre soldado mobilizado após 1939. Os dois personagens, forjados nessas duas experiências, por assim dizer, de reclusão, são as vozes que nos enunciam os traços iniciais da teoria fenomenológica satriana da subjetividade. São também os avatares pelos quais Sartre introduz, sob forma propositiva, sua recepção da literatura contemporânea, cuja leitura crítica, via O som e a fúria de Faulkner, acabamos de expor.

5.2 Se tomamos A náusea como texto literário privilegiado no eixo fenomenológico do pensamento de Sartre é porque (1) ele foi elaborado de forma conjunta - também já o mencionamos ${ }^{72}$ - aos primeiros artigos de fenomenologia, dentre os quais Uma ideia fundamental...; ao mesmo tempo (2), A náusea se sobressai, se comparada a outras publicações do período como os contos de $O$ muro, no desenvolvimento do estilo literário cujas principais influências são, conforme demonstramos até aqui, as ideias de Husserl, as técnicas cinematográficas e os

\footnotetext{
${ }^{68}$ Ibidem, p. 73.

${ }^{69}$ Cf. HAMMEL, Yan. "Pour um roman français à l'américaine: Jean-Paul Sartre critique littéraire". In: Études françaises, Montréal, vol. 43, n. 3,2007 , pp.41-54, para uma análise do significado e do alcance do paralelo traçado por Sartre entre os romances contemporâneos franceses e norte-americanos. No entanto, não concordamos totalmente com o autor: não vemos uma preferência absoluta de Sartre pelos estadunidenses sobre os franceses; as resenhas reunidas em Situaçōes I sobre Nizan e Camus, sobretudo, impedem essa interpretação. O que há, sim, é o reconhecimento de que escritores como Dos Passos, Hemingway e Faullkner marcam um desprendimento mais maduro (do que em geral os franceses) em relação à influência de metafísicas antiquadas sobre a técnica romanesca - e mesmo assim, como vimos, esse desprendimento permanece apenas parcial.

${ }^{70}$ SARTRE, Jean-Paul. "À propos de Le Bruit et la Fureur. La temporalité chez Faulkner", op. cit.., p. 74.

${ }^{71}$ Sobre o conteúdo autobiográfico de $A$ náusea e a inscrição do tema e dos personagens do romance nas experiências, contatos e influências do jovem Sartre, cf. ARNOLD, James. "La nausée revisited". In: The french review, vol. 39, n. 2, 1965, pp. 199-213.

${ }^{72}$ Cf. nota 7 acima.
} 
romancistas norte-americanos. Nosso argumento é que, assim como em 1943 o ser e o nada assumirá as tendências filosóficas que contagiam o pensamento sartriano e lhes desenvolverá as consequências em termos de uma ontologia, em 1938 A náusea assimila e aperfeiçoa as tendências estéticas, representando a face literária desse momento de formação intelectual. Ao passo que temos ali um "ensaio de ontologia fenomenológica"773, teríamos aqui um romance fenomenológico. A contemporaneidade histórica e conceitual entre o romance e os artigos teóricos produz o perfeito alinhamento entre narratividade e reflexão filosófica que será marca da literatura sartriana. O procedimento é em larga medida responsável pela tonalidade cativante do texto, mas também contribui para sua caracterização, pela crítica, como roman à these. Este juízo não passa, porém, sem questionamento se percebermos como a técnica de Sartre prima pela permeabilidade entre o enredo e a ideia e evita o encapsulamento daquele pela última, elevando o romance à posição de elemento, não ilustrador, mas fundador, ele mesmo, do conceito ${ }^{74}$. É possível observar, assim, a tensão de certas passagens de $\mathbb{A}$ náusea que parecem vacilar, em termos de estilo de escrita, entre o ensaio e a narrativa, entre a descrição fenomenológica e a anotação de diário. Várias passagens do texto nos põem diante dessa perspectiva. Por exemplo:

Eu era a raiz de castanheiro. Ou antes, era por inteiro consciência de sua existência. Ainda separado dela - pois tiinha consciência dela - e no entanto perdido nela, nada mais senão ela. Ūma consciência pouco à vontade e que todavia se abandonava com todo o seu peso, instavelmente, sobre aquele pedaço de lenho inerte ${ }^{75}$.

Ou, mais adiante:

Agora, quando digo "eu", isso me parece oco. Mal consigo sentir a mim mesmo muito bem, de tal modo estou esquecido. Tudo o que resta de real em mim é existência que se sente existir. Bocejo suave, demoradamente. Ninguém. Antoine Roquentin não existe para ninguém. Isso me diverte. $\mathbb{E}$ o que é isto, afinal Antoine Roquentin? É algo de abstrato. Ūma pálida e tênue lembrança de mim vacila em minha consciência. Antoine Roquentin... E de repente o Eu esmaece, esmaece e, pronto, some. Iúcida, imóvel, deserta, a consciência se encontra entre as paredes; perpetua-se. Já ninguém a habita [...] Restam paredes anônimas, uma consciência anônima. Eis o que há: paredes, e entre as paredes, uima pequena transparência viva e impessoal ${ }^{76}$.

Apesar, portanto, de sua ocupação eminentemente historiográfica (ele vai a Bouville em busca de material para compor a biografia do marquês de Rollebon), Roquentin é um fenomenólogo. Se a primeira passagem não bastasse para nos convencer disto - a imagem do castanheiro em clara sintonia com a da árvore torcida de Uma ideia fundamental.o. - a segunda o tornaria evidente. Pois não é o caráter exterior, secundário e subalterno do Eu em relação à consciência, tese central de $A$ transcendência do ego, que Roquentin intui nessa estranha reflexão interior, a qual termina por acusar a absoluta debilidade da personalidade diante da existência anônima e impessoal? Nesse quadro, a náusea que atormenta o protagonista equivale ao resíduo sintomático de um processo em nada menor que a conversão fenomenológica proposta pela doutrina husserliana. As anotações diárias de Roquentin nos permitem, assim, perfazer o trajeto da atitude natural - o contato ingênuo, cotidiano, impensado com o mundo - à atitude

\footnotetext{
${ }^{73}$ Subtítulo de O ser e o nada.

${ }^{74} \mathrm{Cf}$. CONTAT, Michel; IDT, Geneviève, op. cit., p. Xv: "[nos romances de Sartre] as ideias tomam o lugar que a psicologia ocupava nos romances anteriores: elas contam. Noutros termos, elas têm uma função dramática na própria narrativa e testemunham sobre a época que lhes engendrou e na qual repercutiram".

${ }^{75}$ SARTRE, Jean-Paul. La nausée Paris: Gallimard, 2004, p. 187.

${ }^{76}$ Ibidem, p. 239. 
fenomenológica, isto é, a atitude reflexiva que busca, mediante a suspensão das hipipóteses e dos saberes, reconstituir a essência do encontro entre o subjetivo e o real.

5.2a Podemos, então, considerar a náusea de Roquentin como um exercício, ainda que neste caso involuntário, de conversão fenomenológica, desde que ressaltemos - caráter irreversível desta experiência. No romance, as camadas da familiaridade objetiva que desabam não podem ser repostas, nada pode ser hipotética ou provisoriamente suspenso. Há uma fatalidade no dado de que o trato com a realidade nunca mais voltará a ser o mesmo. Daí que se possa falar de uma mudança cujo sentido vai além de uma meditação intelectual e que lança raízes no plano ontológico-existencial, ou seja, no próprio plano de nossa relação com o ser, mudança essa que Franklin Leopoldo, em notável acurácia verbal, descreve como uma metamorfose:

A metamorfose significica que a confiança que até então se depositava no ser das coisas desmorona. A suspensão da îmagem habitual do mundo e sua substituição pelo bizarro e pelo não-previsível configuram assim a peirda de estabilidade que as coisas detinham quando possuíam a aparência de ser. É nesse sentido que as coisas se desvelam precisamente quando deixam de ser, já que o ser que as caracterizava consistia somente na projeção do conjunto de expectativas do sujeito ${ }^{77}$

Esta interpretação da conversão como metamorfose nos conecta a uma interessante chave de leitura sobre o enredo de $A$ náusea, a saber, os vestígios de uma proximidade temática com $A$ metamorfose de Franz Kafka (afinidade que não escapou às mais afinadas resenhas do romance, como a de Albert Camus ${ }^{78}$ ). Não é preciso esforço para encontrar os tópicos em comum: a transformação súbita mediante a qual o sujeito se depara com a luta para compreender e ser compreendido como questão de vida ou morte; a irrupção da viscosidade como reino originário das coisas e dos corpos em geral, uma vez desfeita a camada do hábito e da convenção que se revela o medium ético e mesmo ontológico da sociabilidade burguesa; a descrição da degradação, ou ainda da debilidade, como vetor fundamental da existência ${ }^{79}$. Por último, năo deixa de ser interessante atentarmos também para o saldo invertido da insistência entomológica nos dois romances: enquanto n'A metamorfose o protagonista acorda inseto, Roquentin mais de uma vez percebe um arremedo de transmorfismo insetal nos objetos ${ }^{80}$.

5.3 Gostaríamos de avançar a ideia de que a narratividade de $A$ náusea não fica atrás, muito menos para simplificá-los, dos textos propriamente fenomenológicos de Sartre. Que, pelo contrário, ela vai mais longe, em termos de introdução de ideias, do que permite a delimitação teórica típica dos ensaios filosóficos - o que implica a inclusão obrigatória do estudo do romance em qualquer programa de leitura, crítica ou expositiva, da fenomenologia sartriana. Para fazê-lo, trataremos de focalizar uma perspectiva que o romance procura construir e que optaremos por denominar perspectiva de desmanche. Ao nosso ver, essa perspectiva é projetada, em A náusea, a partir de quatro vetores principais: metafísico - na crítica à generalização do regime de causalidade necessária; psicológico - no abandono da centralidade da identidade pessoal, ou do $\mathbb{E} u$; temporal - na suspensão da organização linear e causal dos acontecimentos; e, em estreita ligação com o anterior, narrativo - na dupla restrição do ponto de vista e da temporalidade narrativa.

5.3a A experiência da náusea encarna o desvelamento da crueza íntima das coisas, cuja absoluta estranheza, em relação às ideias que delas fazemos, denuncia a fragilidade dos esquemas de compreensão e assimilação a partir dos quais lhes

${ }^{77}$ SILVA, Franklin Leopoldo e. Ética e literatura em Sartre: ensaios introdutórios. São Paulo: Editora UNESP, 2004, p. 82; grifos do autor.

${ }^{78}$ CAMUS, Albert. "'La nausée' de Jean-Paul Sartre". In: CAMUS, Albert. Essais. Paris: Éditions Gallimard et Calmann-Lévy, 1965.

79 "Todo existente nasce sem razão, perpetua-se por fraqueza e morre por acaso". SARTRE, Jean-Paul. La nausée, op. cit, p. 190.

${ }^{80}$ Ibidem, p. 117 e pp. 143-144 
abordamos ${ }^{81}$. A situação de Roquentin é a de quem é lançado sem avisos diante da coisaem-si kantiana. Mas sabemos desde 1781 que a condição para que tal encontro seja possível é que deixemos de ser o que somos. Daí que Sartre perceba na fenomenologia, enquanto método de intuição das essências, uma imediata subversão da ideia de subjetividade. O clímax do romance, o choque que Roquentin experimenta no jardim público de Bouville, aponta para o fato de que as essências das coisas, embora sejam intuíveis ou experimentáveis, não se dobram à nossa costumeira exigência de inteligibilidade dedutiva. A contingência fundamental dos entes implicando toda uma série de contingências secundárias, entre as quais a do próprio conhecimento enquanto atitude que viria definir a especificidade da realidade humana perante as demais.

O essencial é a contingência. Quero dizer que, por definição, a existência não é a necessidade. Existir é simplesmente estar aŕ, os existentes aparecem, deixam que os encontremos, mas nunca podemos deduzi-los [...] A contingência não é um simulacro, uma aparência quie se pode dissipar; é o absoluto, por conseguinte a perfeita gratuidade. Tudo é gratuito: esse jardim, essa cidade, eu próprio ${ }^{82}$

O primado da contingência desmancha a perspectiva filosófica, e também científica, da dedução dos entes e dos eventos segundo a ideia de causalidade necessária. Não porque essa ỉdeia não teria um lastro empírico, como queria Hume, mas por conta de sua incompatibilidade com a natureza singularmente opaca de cada coisa. As relações, as funções e as articulações das partes no todo podem ser perfeitamente previstas e calculadas, mas a existência, o estar-aí de cada coisa não se deixa compreender, se compreender significa integrar num sistema de categorias. Dado que "o mundo das explicações e das razões não é o da existência" ${ }^{" 13}$ - essa a tese metafísica do romance -, o reino das coisas e o do espírito só podem ser conciliados, não pela reflexão, mas pela experiência ${ }^{84}$.

5.3b Ato contínuo ao desvelo da contingência dos entes em geral, dá-se o da contingência da própria identidade. E aqui Sartre se serve de uma interessante simultaneidade nos dois planos da narrativa: é que a mudança que acomete Roquentin em sua rotina pessoal duplica-se em sua pesquisa sobre a biografia do marquês, abandonada, em parte, devido à fragmentação e às lacunas insuperáveis na vida do aristocrata. A descoberta da impossibilidade de uma relação estável com a realidade é seguida de muito perto pela frustração na reconstituição da vida de um indivíduo a partir do esquema personalidade-intenções-projetos-ações cuja linearidade permitiria atestar os motivos, o destino e o caráter de alguém ${ }^{85}$. O produto entre esses dois fracassos é a constatação do caráter opaco e fugidio do Eu, cuja consistência é inversamente proporcional à evidência do fluxo de consciência, das ações concretas e da facilidade pela qual o sujeito toma a si mesmo como objeto de reflexão. Essa relação é bem descrita na passagem que citamos há pouco ${ }^{86}$, em que o "acréscimo" da transparência da consciência para si mesma provoca o esmaecimento gradual da identidade egológica. De qualquer forma, para o protagonista, sua realidade presente e a decifração do passado do marquês estavam de tal forma entrelaçadas que seria difícil

81 Veja-se a crítica da "filosofia alimentar" em SARTRE, Jean-Paul. "Une idée fondamentale de la phénoménologie de Husserl: I'intentionnalité", op. cit., p.87.

${ }^{82}$ SARTRE, Jean-Paul. La nausée, op. cit, p. 187; grifos do autor.

${ }^{83}$ Tbidem, p. 184.

84 "Ao afirmar a irredutibilidade do existir ao conhecer, Sartre torna a existência cúmplice das figuras do inconcebível: a contingência, o acaso, o injustificável, o absurdo. $\mathrm{E}$ ao afirmar a primazia da consciência não reflexiva sobre a reflexão, atribui ao cogito uma dimensão existencial que se dá num plano pré-reflexivo" (MARTON, Scarlet. "Sartre: ontologia e historicidade”. In: O que nos faz pensar, Rio de Janeiro, n. 21, 2007, pp. 5 19).

${ }^{85}$ SARTRE, Jean-Paul. La nausée, op. cit, p. 29: "Não é que me faltem documentos: cartas, fragmentos de memórias, relatórios secretos, arquivos de polícia. Pelo contrário, tenho disso tudo até demais. o que falta em todos esses testemunhos é a firmeza, a consistência. Não, eles não se contradizem, mas também não concordam entre sí, não parecem dizer respeito à mesma pessoa."

${ }^{86}$ Cf. Ibidem p. 239 
apontar qual aspecto sustentava o outro. "O sr. de Rollebon era meu sócio: ele precisava de mim para ser, e eu precisava dele para não sentir meu ser"87. As perguntas "Quem foi Rollebon?" e "Quem é Roquentin?" exigiam uma mesma resposta e acabaram soterradas pelo mesmo silêncio da contingência. Alojado e como que cultuado pela consciência, o Eu se retroalimenta da ilusão de ser o centro da subjetividade. Mas se a verdade da consciência é a intencionalidade, e se a subjetividade resume esse movimento perpétuio de consciências-de... que prescinde de unificação a posteriori, então o $\mathbb{E u}$ não deve aparecer à atitude fenomenológica como mais do que um equívoco ou uma ilusão ${ }^{88}$ que a contingência radical, em sua função purificadora, deve desmanchar.

5.3c Outra significativa frustração que acomete Roquentin está em que a náusea refuta o sentimento de aventura ${ }^{89}$, a expectativa de experiências já formatadas conforme o modelo da narrativa, experiências que podem depois vir a ser transmitidas, encenadas, proporcionando uma breve suspensão da contingência. Roquentin, para sua tristeza, descobre a falsidade de tal ideia da vida como um "encadeamento rigoroso das circunstâncias"90. A possibilidade disto que denominamos vida equivale à impossibilidade de algo como a aventura, pois, se o aspecto fundamental desta última é certo télos graças ao qual ela aparece sempre como narrável, aquela é atravessada permanentemente, e de ponta a ponta, por uma contingência constitutiva que faz com que cada evento seja um possível entre $n$ eventos, cada escollha uma possível entre $n$ escolhas. Posto que $n$ nunca pode ser, no instante, inteiramente determinado, ele é virtualmente infinito. Daí o pavor de Roquentin ao constatar que "tudo, tudo pode acontecer"91. Enquanto a aventura pressupõe um trajeto, um destino, um curso de ações mais ou menos engessado - o bastante para poder ser transmitido numa linearidade repetível -, a vida não se narra, já que a consciência que se tem do que está para ser vivido é sempre, por princípio, incompleta. É fácil ver como essa reflexão como que respinga numa proto-concepção de História na qual a marca distintiva do acontecimento ou do processo histórico é a fratura entre sua experiência e seu sentido. A História depende da realidade humana numa dupla dimensão: para ter seu efeito imediato captado e para ser assumida enquanto tal. Mas o processo sempre pode ser reconstituído à distância, sem que haja referência concreta e repleto de defasagens. Ao mesmo tempo, o acontecimento presenciado sempre pode ser obliterado, pode nunca ser integrado à lógica maior de explicação do passado. Vista por esse ângulo, a História parece ser capaz de comportar tudo, menos a verdade. Daí que ela seja definida de forma tão frequente como campo de perpétua disputa de narrativas. Paradoxalmente, só podemos concebê-la assim na medida em que a compreendemos como o absoluto avesso da narrativa ${ }^{92}$. Isto nos leva ao quarto ponto.

${ }^{87}$ Ibidem, p. 143.

${ }^{88}$ A certa altura, Roquentin avalia sua tentativa de biografia do marquês nos termos: "tenho a impressão de fazer um trabalho de pura imaginação" (Ibidem, p. 30). Cf. a interessante análise psicanalítica desse processo de desmanche do Eu em POIANA, Peter. "The subject as symptom in Nausea". In: ROLLS, Alistair; RECHNIEWSKI, Elizabeth (eds.). Sartre's Nausea: text, context, intertext. Amsterdam: Rodopi, 2008.

${ }^{89}$ SARTRE, Jean-Paul. La nauséei, op. cit.. p. 60 et seq.

${ }^{90}$ Ibidem, p. 43

${ }^{91}$ Tbidem, p. 115.

${ }_{92}$ Thana Mara de Souza desenvolve a tese, com a qual não poderíamos deixar de concordar, da pertinência da reflexăo histórica aos escritos fenomenológicos e aos primeiros romances sartrianos. A autora argumenta por uma crítica, subjacente ao enredo de A náusea, à historiografia tradicional centrada nos indivíduos e nos feitos e pela adesão a uma concepção de história na qual os projetos humanos (em sua contingência e incompletude constitutivas) são os nódulos fundamentais do processo histórico: "não se trata de pensar mais a História com H maiúsculo, como história de datas e heróis, de grandes feitos. A história não contém certezas e uma ordem rigorosamente lógica, e isso porque é feita por nós, seres humanos comuns, Para-sis que necessariamente buscam em vão ser o que nunca serăo, a completude" (SOUZA, Thana Mara de. "A presença da história no 'primeiro' Sartre: Roquentin e a náusea frente a ilusão da aventura histórica". In: Princípios, Natal, v. 16, n. 26 , 2009 , pp. 87-105, p. 100). Isso posto, complementaríamos nossa afirmação à p. 14 acima dizendo que o modo como contamos o tempo determina o modo como contamos uma história e o modo como contamos a História. Temos em mente, com a reabilitação da historicidade aos textos e romances sartrianos dos anos 30-40, a formulação, noutra oportunidade, de um contraponto a uma interpretação hegemônica do pensamento de Sartre que se aproveita de suas distintas aproximaçōes teóricas com a fenomenologia e o marxismo para 
5.3d A narratividade que se queira o mais próxima possível da experiência vivida tal como ela é, constitutivamente contingente, incompleta, desprovida de sentido imediato, precisa, portanto, reorganizar os artifícios tradicionais da arte literária de forma a superar uma série de obstáculos. Se quisermos projetar sobre a obra Sartre seu próprio princípio crítico, devemos procurar n’A náusea uma técnica narrativa que faça jus a uma concepção fenomenológica do tempo e da consciência orientada por uma metafísica da contingência. Pelo menos dois traços dessa técnica saltam à vista na superfície do texto. O emprego da primeira pessoa sob a voz do narrador protagonista procedimento segundo o qual Roquentin aparece vítima, advogado, acusador e juiz do próprio caso, escrevendo, como diz, "ao correr da pena" entregando um instantâneo do sujeito descentrado de si e imerso na vaga dos fenômenos. E o escalonamento da temporalidade narrativa ao nível do diário, o que estabelece um intervalo mínimo entre a experiência e a escrita e permite que (1) a primeira seja clinicamente anotada, a história sendo contada quase ao mesmo tempo em que é vivida, e que (2) o futuro seja constantemente re-aberto. Claro, aquii tudo que se pode obter é uma aproximação pela qual a oposição entre história e estória vai ser, no máximo, retraída. Ainda assim, Sartre funda com $A$ náusea uma narratividade que vai ao encontro da historicidade, de forma que não é exagero ver no romance os primeiros esboços literários das formulações tipicamente dialéticas da Filosofia da História sartriana ${ }^{94}$.

5.4 Visitemos muito rapidamente as interseções do romance fenomenológico com outras formas de expressão artística. Para esse propósito, é oportuno retomar nossa hipótese de uma teoria cinematográfica comandando as reflexões fenomenológica e literária sartrianas. De fato, é curioso como a linha estética tecida pela obra de Sartre do cinema à literatura inverte a ordem histórica da interferência entre as duas artes: um dos primeiros grandes confrontos travados pelo cinema em seu processo de autoafirmação artística foi a elaboração de uma lógica narrativa que rompesse com a estrutura romanesca e a representação teatral. Em Sartre o que testemunhamos é o esforço para fazer o cinema penetrar o romance. Faz-se obrigatório aí o recurso a uma técnica realmente transgênica no sentido de incorporar elementos tão heterogêneos à narratividade literária como a montagem, a disposição cenográfica, a transição dos planos e a modulação das tomadas ${ }^{95}$. Tudo isso é traballhado em $A$ náusea, sob o auspício da dupla irregularidade - temática e de extensão - que só o estilo fragmentado do texto proporciona. É que os efeitos cinematográficos não podem ser simulados na estruturação capitular tradicional dos romances (favorável, por outro lado, aos projetos de adaptação). O contraste entre a menor entrada no diário - "Terça. Nada. Existido"966 - e uma das maiores, a que descreve a cena no jardim público, indicia um arranjo de variação sobre a quantidade e a duração dos quadros pelo qual o leitor passar de um tema ao outro num ritmo propriamente fílmico, isto é, que dispensa intermédio e introdução. A facilidade com que se passa, na leitura, de um desses estratos ao seguinte dá mostras de uma preocupação estética absolutamente cinematográfica com a transição espontânea, além de funcionar como perfeita tradução imagética da intencionalidade.

afirmar dois cursos metodológicos e temáticos distintos em sua fillosofia, um metafísico-ontológico e outro histórico-político.

${ }^{93}$ SARTRE, Jean-Paul. La nausée, op. cit, p. 87.

${ }_{94}$ Uma quinta linha do desmanche de A náusea o antropológico - na ridicularização das pretensões equivocadas do humanismo de concepção burguesa. Mas o tópico exige uma articulação conceitual e textual mais ampla cujo desenvolvimento é inviável no curso deste artigo.

${ }^{95}$ Além disso, George Wodds (WOODS, George. "Sounds, 'sounds, smells, degrees of light': art and illumination in Nausea". In: ROLLS, Alistair, RECHNIEWSKI, Elizabeth (eds.). Sartre's Nausea: text, context, intertext. Amsterdam: Rodopi, 2008) desenvolve um excelente estudo da, digamos, estética fenomenológica da luz e das cores em A náusea: "Esta função diretiva da luz em $A$ náusea é comparável à sua função nas artes visuais e pode ser lida através do papel que luz e percepção desempenham em três movimentos de artes visuais: Surrealismo, Impressionismo e Cubismo" (p. 54).

${ }^{96}$ SARTRE, Jean-Paul. La nausée, op. cit., p. 149. 
5.4a Mas é talvez em Sursis que a transposição de técnicas cinematográficas para a literatura é levada mais longe. O segundo volume de Os caminhos da liberdade repousa numa ideia de contração do tempo cujo equivalente factual é a semana de véspera do Acordo de Munique. Aqui a leitura sartriana de Dos Passos combinada ao elogio da polifonia cinematográfica ${ }^{97}$ resulta em uma anomalia narrativa de dissonância das perspectivas: elas nãos se encontram e nesse desencontro inviabilizam uma regência narrativa capaz de dar linearidade ao romance. O que não implica uma ausência de sentido e unidade da obra: a dissonância das perspectivas dá conta da dissonância das diversas temporalidades, o que por sua vez dá conta da dissonância das consciências; estas consciências desencontradas estão, contudo, conectadas pela experiência histórica, e devem todas versar, de dentro das multidões onde se perdem, sobre a mesma mescla de fatores psicológicos - o desamparo, o medo, a expectativa do conflito iminente - e políticos - o exílio, a miséria, a mobilização, os atentados - que determinam sua grande circunstância. Essa convergência é arranjável através da focalização num gesto ou num objeto. Nesta passagem, a título de exemplo, é um guardanapo que põe em cena personagens separados por quilômetros de distância:

Atrás das persianas fechadas, eles cozinhavam a vapor, Daniel pôs o guardanapo sobre os joelhos, Hannequin o atou ao pescoç, Brunet pegou o guardanapo de papel sobre a mesa, amarrotou-o e limpou os lábios, Jeannine empurrou Charles para o grande refeitório quase deserto, de vidraças riscadas de giz, e estendeu-lhe o guardanapo no peito ${ }^{98}$.

A polifonia cinematográfica aparece frequentemente em Sursis como uma simultaneidade de consciências regida por um elemento comum. O emprego do recurso fílmico na representação da subjetividade literária, contudo, não obedece aqui à mera estética; ele se vincula, pelo estreitamento daquela distância entre história e narração, a um compromisso com a enunciação do evento histórico: "nosso problema técnico é encontrar uma orquestração de consciências que nos permita dar conta da pluridimensionalidade dos acontecimentos ${ }^{\prime \prime 9}$, Sartre explica. Mas devemos nos deter aí, no registro da apropriação literária do cinema, a fim de não ultrapassar o escopo da literatura fenomenológica e adentrar o domínio da literatura engajada.

5.5 Se procuramos ler A náusea como um texto fenomenológico, como um romance de desmanche ou como um experimento de narratividade cinematográfica, não devemos deixar passar o fato de que sob a estrutura de camadas do enredo e de jogos de oposições - entre vida e aventura etc. - que lhe sustenta (podendo-se falar até numa montagem romanesca), está o projeto de um "panfleto sobre a contingência"1100. Some-se a isso a visualização da oposição lógica entre a contingência radical constitutiva da existência e a necessidade implícita na obra de arte, conforme os casos do filme e da narrativa. O resultado é uma situação na qual a temática da obra se contrapõe naturalmente à sua condição estética de possibilidade. A náusea seria, assim, uma tentativa de incursão nos limites da arte; melhor dito: de demarcação do limite da arte quanto à expressão da existência. Essa tentativa é pautada no texto pela experiência musical: bastam as primeiras notas de Some of these days para que Roquentin seja provisoriamente salvo da contingência dramática da existência e transportado ao reino das essências, ordem na qual a aventura é novamente possível, a vida é narrável e a

97 Cf. p. 12, acima, neste artigo. E também: "Eu quils ao mesmo tempo evitar fallar de uma multidão ou de uma nação como se fala de uma pessoa, atribuindo-lhe gostos, vontades e representaçôes, como o faz Zola em Germinal, e reduzi-la à soma dos elementos que a compóem. Tentei aproveitar as pesquisas técnicas conduzidas por certos romancistas da simultaneidade como Dos Passos e Virginia Woolf. Retomei o projeto na altura onde eles o deixaram, e procurei lhe acrescentar alguma novidade" (SARTRE, Jean-Paull. "L'âge de raison - Prière d'insérer". In: SARTRE, Jean-Paul. Otuvres romanesques. Paris: Gallimard, 2009, p. 1912).

${ }^{98}$ SARTRE, Jean-Paul. "Sursis". In: SARTRE, Jean-Paul. OEvvres romanesques. Paris: Gallimard, 2009, p. 98.

99 SARTRE, Jean-Paul. "Qu'est-ce que la littérature?". In: SARTRE, Jean-Paul. Situations, II Paris: Gallimard, 1968, p. 327, o grifo é nosso.

${ }^{100}$ COHEN-SOLAL, Annie, op. cit. p. 132 et seq. 
trajetória dos seus dias anódinos pode ser linearmente reconstituída, tal como a dos dias do marquês de Rollebon. Salvação é de fato a palavra certa; o rigor da música ${ }^{101}$ é o lugar de uma consciência que coincide com seu Eu, de objetos cujas aparências coincidem com - ser. A música faz a existência coincidir com a essência, num constructo ideal que dura até o desabar da última nota. Depois disso, resta a realidade. A vida, a contingência e a náusea emergem novamente. Sartre parece inscrever um sinal de exclusão entre a arte e a vida ${ }^{102}$. Nem a primeira pode integrar a segunda, sob pena de se decompor, nem a segunda pode integrar a primeira, a não ser da perspectiva do passado, quando a vida deixa de ser vida e se transmuta em destino ${ }^{103}$. A soteriologia da obra de arte é contestada - ou, se quisermos, desmanchada -, pois embora a arte sublime a existência, não é capaz de suprimi-la em nome de uma essência estável nem de assumi-la radicalmente em sua instabilidade. A arte, idealidade sujeita à duração, é por princípio votada ao fracasso. O desmanche fenomenológico operado em $A$ náusea inclui, portanto, a exposição desse fracasso fundamental ${ }^{104}$.

\section{$\S 6$ Uma metafísica literária?}

6.1 Sabe-se que Sartre nunca publicou um ensaio de metafísica, mesmo reconhecendo a emergência de problemas desse tipo a partir de suas descobertas no campo da ontologia ${ }^{105}$. Compreendemos também, a esta altura, como o estatuto de sua literatura lhe permite tematizar questões tradicionalmente metafísicas - o sentido do tempo, a ordem causal, as tensões entre existência e essência e entre contingência e necessidade, os fundamentos e os limites da identidade e da inteligibilidade dos entes. Uma derradeira ideia que arriscaríamos introduzir a partir do quadro de nossa análise, portanto, é a da assunção da reflexão metafísica pelo projeto literário de Sartre. Tratarse-ia de pensar como seus contos, romances, textos de crítica e afins cuidam das questões metafísicas que seus ensaios filosóficos enunciam sem desenvolver até o fim. Restaria assim pensar, na obra de Sartre, além de uma fenomenologia cuja expressão tende à literatura e de vuma literatura que toma a fenomenologia por baliza teórica, uma metafísica literária, não explicitamente tematizada pelo autor, não intitulada como tal, porém não menos fecunda e determinante para a totalidade de seu pensamento ${ }^{106}$. $\mathbf{A}$ imbricação fenomenologia-literatura é relevante, nesse sentido, não apenas para que as pesquisas fenomenológicas e literárias de Sartre possam ser analisadas em sua mutualidade constitutiva, como também para que se possa determinar em que medida esse circuito expressivo dá conta dos temas adjacentes à ontologia e à reflexão política que são as preocupações centrais da filosofia sartriana ${ }^{107}$.

\footnotetext{
${ }^{101}$ Cf. a descrição apaixonada do rigor da obra musical em SARTRE, Jean-Paul. La nausée, op. cit., p. 149. CARROLL, Mark. "It is': reflections on the role of music in Sartre's 'La nausée". In: Music \& Letters, Oxford, vol. 87, n. 3, 2006, pp. 398-407; e WEIDMANN, Artur Ricardo de Aguiar. "O efeito do jazz em A náusea de JeanPaul Sartre". In: ArteFilosofia, Ouro Preto, n. 21, 2016, pp. 145-159 lançam uma boa discussão sobre a função da música para Roquentin como salto da contingência à necessidade e da existência à essência.

102 "É preciso escolher. viver ou narrar" (SARTRE, Jean-Paul. La nausée, op. cit., p. 64).

${ }^{103}$ SARTRE, Jean-Paul. L'être et le néant. Paris: Gallimard, 1976, p. 150.

${ }^{104}$ O pós-texto do romance nos informa, aliás (SARTRE, Jean-Paul. La nausée, op. cito, pp. 249-250), que a derradeira tentativa de Roquentin de alcançar uma espécie de conciliação metafísica na escrita literária também fracassa. Seu diário, que poderia vir a ser transformado num livro, é abandonado, e suas notas só são publicadas muito depois, sob os cuidados de um editor anônimo (Sartre).

${ }^{105}$ Cf. SARTRE, Jean-Paul. L'être et le néant, op. cit., p. 665 et seq.

${ }^{106}$ Cf. FRAJOLIET, Alain. "Literature and phillosophy in Sartre's early writings". In: Sens public, 2007. Michel Contat e Michel Rybalka discutem, a propósito, as variações da posição sartriana a respeito do "valor metafísico da literatura" (CONTAT, Michel; RYBALKA, Michel. "La nausée - Notice". In SARTRE, Jean-Paul. OEuvres romanesques. Paris: Gallimard, 2009, p. 1673).

${ }^{107}$ Seria o caso de visualizar a literatura como necessária "para o equacionamento da problemática da existência segundo o projeto filosófico de fundo ético de Sartre", isto é, como "o último recurso capaz de manter o questionamento da existência na forma interrogante" (GERMANO, Emanuel Ricardo. A dimensão ética da revolta em Albert Camus: filosofia, politica e arte. Fortaleza: EDUFC, 2012, p. 167; o autor destaca).
} 
6.2 Diríamos, então, de forma a sumarizar nossas considerações finais, que a leitura dessa imbricação nos incita a levantar três questões. (1) Serão os princípios dos "esboços metafísicos"108 anunciados em 0 ser e o nada desenvolvidos e desdobrados no projeto literário sartriano? (2) Se os textos fenomenológicos apontam as ideias diretrizes da técnica literária e a produção (somada à crítica) literária remete às ideias fenomenológicas, será então essa suposta metafísica literária elucidável como uma metafísica fenomenológica? (3) De forma geral, serão os projetos inconclusos (do ponto de vista filosófico) do pensamento sartriano, tais como a reflexão metafísica, conceitualmente resgatados a partir das obras para-filosóficas ${ }^{109}$ de Sartre? Respostas a essas questões hão de ser desenvolvidas noutro lugar. Por ora devemos ressaltar sua função, além de interpretativa, indicativa no que concerne à elaboração de um imperativo metodológico imprescindível à análise dos escritos sartrianos, a saber: o abandono da distinção rígida entre filosofia e não-filosofia - mais especificamente entre filosofia e literatura -, que no caso de Sartre convida a uma avaliação mais formal do que propriamente material do texto ao postular a falsa dualidade entre o artista e o filósofo.

\section{Referências}

ARNOLD, James. "La nausée revisited". In: The french review, vol. 39, n. 2, 1965, pp. 199213.

BASTOS, Jackson Valentim. "Sartre, Faullkner e a técnica literária como expressão do humano". In: Mimesis, Bauru, vol. 32, n. 1, 2001, pp. 19-28.

BEAUVOIR, Simone. La force de l'âge. Paris: Gallimard, 1960.

BERGSON, Henri. "L'évolution créatrice". In: BERGSON, Henri. CEuvres. Paris: PUF, 2001.

CAMPOS, Carolina Mendes; ALT, Fernanda; EWALD, Ariane P. "A interrelação filosófico-literária do pensamento de Sartre: bases para uma psicologia fenomenológica do Eu". In: Revista de abordagem gestáltica, Goiânia, vol. 15, n. 9, 2009, pp. 126-132.

CAMUS, Albert. "La nausée' de Jean-Paul Sartre". In: CAMUS, Albert. Essais. Paris: Éditions Gallimard et Calmann-Lévy, 1965.

CARROLL, Mark. "It is': reflections on the role of music in Sartre's 'La nausée". In: Music \& Letters, Oxford, vol. 87, n. 3, 2006, pp. 398-407.

CHATEAU, Dominique. Sartre et le cinéma. Paris: Séguier, 2005.

COHEN-SOLAL, Annie. Sartre. Trad. Milton Persson. São Paulo: L\&PM Editores, 1986.

CONTAT, Michel; RYBALKA, Michel. "La nausée - Notice". In SARTRE, Jean-Paul. CEuvres romanesques. Paris: Gallimard, 2009.

CONTAT, Michel; IDT, Geneviève. "Préface". In SARTRE, Jean-Paul. OEuvres romanesques. Paris: Gallimard, 2009.

COOREBYTER, Vincent de. "Introduction". In: SARTRE, Jean-Paul. La Transcendence de l'Ego et autres textes phénoménologiques. Paris: Librarie Philosophique J. Vrin, 2003.

CONNOR, J. D. "Sartre and Cinema: The grammar of commitment". In: MLN. Baltimore, v. 116, n. 5, 2001, pp. 1045-1068.

DANELON, Márcio. "A temporalídade na constituição da consciência na antropologia sartriana”. In: Reflexão, Campinas, vol. 30, n. 87, 2005, pp. 95-110.

${ }^{108}$ SARTRE, Jean-Paul. L'être et le néant, op. cit., p. 665.

${ }^{109}$ Entendemos aqui como para-filosofia a iniciativa intelectual, tão típica à tradição francesa como um todo e particularmente notável em Sartre, de intervir fillosoficamente noutras formas de expressão como as artes (a literatura, o cinema, o teatro...) e as ciências (a psicologia, a antropologia....) e incorporar de volta tais intervenções na reflexăo filosófica. 
DESANTI, Jean-Toussait. "Sartre et Husserl ou les trois culs-de-sac de la phénoménologie transcendantale". In: Les temps modernes, Paris, n. 632-633-634, 2005, pp. 571-584.

FAUTRIER, Pascale. Le cinéma de Sartre. http://www.fabula.org/lht/2/fautrier.html (último acesso em 11/03/19).

FRAJOLIET, Alain. "Literature and philosophy in Sartre's early writings". In: Sens public, 2007 .

GERMANO, Emanuel Ricardo. A dimensão ética da revolta em Albert Camus: filosofia, política e arte. Fortaleza: EDUFC, 2012, p. 167.

HAMMEL, Yan. "Pour um roman français à l'américaine: Jean-Paul Sartre critique littéraire". In: Études françaises, Montréal, vol. 43, n. 3, 2007, pp. 41-54.

JAMESON, Fredric. Sartre. The Origins of a Style. New Haven: Yale University Press, 1961.

MARTON, Scarlett. "Sartre: ontologia e historicidade". In: O que nos faz pensar, Rio de Janeiro, n. 21, 2007, pp. 5-19.

MOUTINHO, Luiz Damon Santos. Sartre: psicologia e fenomenologia. São Paulo: Brasiliense, 1995.

NOUDELMANN, François; PHILIIPE, Gilles. Dictionnaire Sartre. Paris: Honoré Champion, 2004.

OORE, Irène. "Sartre critique de Faulkner". In: Dalhousie French Studies, Halifax, vol. 52, 2000, pp. 127-138.

POIANA, Peter. "The subject as symptom in Nausea". In: ROLLS, Alistair; RECHNIEWSKI, Elizabeth (eds.). Sartre's Nausea: text, context, intertext. Amsterdam: Rodopi, 2008.

PRADO JR., Bento. "Sartre e o destino histórico do ensaio". In: SARTRE, Jean-Paul. Situações, I. São Paulo: Cosac Naify, 2005.

PROUST, Marcel. Du coté de chez Swann. Paris: Gallimard, 1946.

SARTRE, Jean-Paul. "Apologie pour le cinéma. Défense et illustration d'un Art international". In: SARTRE, Jean-Paul. Écrits de jeunesse, Paris: Gallimard, 1990.

SARTRE, Jean-Paul. "À propos de Le Bruit et la Fureur. La temporalité chez Faulkner". In: SARTRE, Jean-Paul. Situations, I. Paris: Gallimard, 1973.

SARTRE, Jean-Paul. "Carnet Midy". In: SARTRE, Jean-Paul. Écrits de jeunesse, Paris: Gallimard, 1990.

SARTRE, Jean-Paul. "Extraits inédits du film 'Sartre par lui-même". In: SARTRE, JeanPaul. CEuvres romanesques. Paris: Gallimard, 2009.

SARTRE, Jean-Paul. "L'âge de raison - Prière d'insérer". In: SARTRE, Jean-Paul. OEuvres romanesques. Paris: Gallimard, 2009.

SARTRE, Jean-Paul. La nausée. Paris: Gallimard, 2004.

SARTRE, Jean-Paul. L'être et le néant. Paris: Gallimard, 1976.

SARTRE, Jean-Paul. "Motion Picture art". In: SARTRE, Jean-Paul. The writings of JeanPaul Sartre. Volume 2: Selected prose. Trad. Richard McCleary. Evanston: Northwestern University Press, 1974.

SARTRE, Jean-Paul. "Qu'est-ce que la littérature?". In: SARTRE, Jean-Paul. Situations, II. Paris: Gallimard, 1968.

SARTRE, Jean-Paul. "Sartoris par W. Faulkner". In: SARTRE, Jean-Paul. Situations, I. 
Paris: Gallimard, 1973.

SARTRE, Jean-Paul。"Sursis". In: SARTRE, Jean-Paul. OEuvres romanesques. Paris: Gallimard, 2009.

SARTRE, Jean-Paul. "Une idée fondamentale de la phénoménologie de Husserl: l'intentionnalité". In: SARTRE, Jean-Paul. La transcendence de l'Ego et autres textes phénoménologiques. Paris: Librarie Philosophique J. Vrin, 2003.

SHAKESPEARE, William. Macbeth. Cambridge: Cambridge University Press, 1999.

SICARD, Michel. Essais sur Sartre. Entretiens avec Sartre (1975-1979). Paris: Ed. Galilée, 1989.

SILVA, Franklin Leopoldo e. Ética e literatura em Sartre ensaios introdutórios. São Paulo: Editora UNESP, 2004.

SILVA, Luciano Donizetti da. "Tempo e temporalidade na filosofia de Sartre". In: Princípios, Natal, vol. 15, n. 24, 2008, pp. 225-248.

SKIRRY, Justin. "Sartre on William Faulkner's metaphysics of time in "The sound and the fury"'. In: Sartre studies international, New York, vol. 7, n. 2, 2001, pp. 15-43.

SoUZA, Thana Mara de. "A presença da história no 'primeiro' Sartre: Roquentin e a náusea frente a ilusão da aventura histórica”. In: Princípios, Natal, v. 16, n. 26, 2009, pp. $87-105$.

WEIDMANN, Artur Ricardo de Aguiar. "O efeito do jazz em A náusea de Jean-Paul Sartre". In: ArteFilosofia, Ouro Preto, n. 21, 2016, pp. 145-159.

WOODS, George. "Sounds, 'sounds, smells, degrees of light": art and illumination in Nausea". In: ROLLS, Alistair" RECHNIEWSKI, Elizabeth (eds.). Sartre's Nausea: text, context, intertext. Amsterdam: Rodopi, 2008.

Doutorando em Filosofia (UFC) E-mail: amster duarte@hotmail.com

Doutor em Filosofia (USP)

Professor Adjunto da UFC E-mail: emanuel.germano@ufc.br 